\title{
A STANDARDIZED BREATH HOLDING TECHNIQUE FOR THE CLINICAL MEASUREMENT OF THE DIFFUSING CAPACITY OF THE LUNG FOR CARBON MONOXIDE ${ }^{1}$
}

\author{
By C. M. OGILVIE,'2 R. E. FORSTER, ${ }^{3}$ W. S. BLAKEMORE, 4 aNd J. W. MORTON s \\ (From the Departments of Physiology and Pharmacology, and Anesthesiology, the Graduate \\ School of Medicine, and the Harrison Department of Research Surgery, School of \\ Medicine, University of Pennsylvania, Philadelphia, Penna.)
}

(Submitted for publication April 16, 1956; accepted August 13, 1956)

Previous publications from this laboratory have described $(1,2)$ a modification of the Krogh breath holding technique for measuring the pulmonary diffusing capacity for carbon monoxide $\left(D_{L}\right) .^{6}$ This test can be performed quickly and simply and does not require arterial blood analyses. It has recently (2) been shown to provide an index of pulmonary diffusing capacity similar to that given by the $\mathrm{DLO}_{2}$ method of Lilienthal, Riley, Proemmel, and Franke (3) and the "steady state" method of Filley, MacIntosh, and Wright (4). The purpose of the present report is to enumerate some of the factors that affect $D_{L}$, to describe a standardized technique for its measurement, and to present

1 Supported by a grant from the Life Insurance Medical Research Fund.

2 Travelling Fellow of the Postgraduate Medical Federation, University of London. Present address: The London Hospital, London.

3 Lowell M. Palmer Senior Fellow.

4 Scholar in Cancer Research of the American Cancer Society.

5 Present address: Division of Tuberculosis Control, Willow Chest Center, 2647 Willow Street, Vancouver 9, B. C.

6 Since the combination of $\mathrm{CO}$ with intracellular hemoglobin occurs at a rate that offers an appreciable, and under some conditions the major, part of the resistance to the uptake of $\mathrm{CO}$ in the lungs $(5,6)$ it is desirable to distinguish between the "true" diffusing capacity, or that of the pulmonary capillary membrane alone $\left(D_{m}\right)$, and the apparent diffusing capacity of the whole lung $\left(D_{L}\right)$. These are related by the equation $1 / D_{L}=1 / D_{m}+1 / \oplus V_{0}$ where $(1)$ is the rate of combination of $\mathrm{CO}$ with intracorpuscular hemoglobin in $\mathrm{ml}$. per min. per $\mathrm{mm}$. $\mathrm{Hg} \mathrm{CO}$ tension per $\mathrm{ml}$. blood, and $\mathrm{V}_{0}$ is the volume of blood in the pulmonary capillaries at any instant. (1) decreases as $\mathrm{O}_{2}$ tension increases $(7)$, causing $D_{\mathbf{L}}$ to decrease, since $D_{m}$ and $\mathrm{V}_{0}$ are presumably relatively independent of alveolar $\mathrm{O}_{2}$ tension (8). Normally a further subscript of $\mathrm{CO}$ or $\mathrm{O}_{2}$ would be used to indicate the gas to which the measurement applies. However, in this article, which is mainly concerned with $\mathrm{CO}$, the subscript is omitted and can be assumed to be "CO" unless otherwise stated. normal values of $D_{L}$ as well as values in patients with various chest diseases.

\section{METHODS}

The technique for the measurement of $D_{L}$, which has been reported before $(1,2)$, consists essentially of having the subject make a maximal inspiration of a gas mixture containing 10 per cent helium $(\mathrm{He}), 0.3$ per cent $\mathrm{CO}$ and approximately 21 per cent $\mathrm{O}_{2}$ in $\mathrm{N}_{2}$ from the level of his residual volume, hold it for a measured time, and then rapidly expire. All of this expiration except the first liter is collected in a bag by the operator and analyzed as alveolar gas. The $\mathrm{CO}$ concentration which was present in this sample before any $\mathrm{CO}$ had been absorbed in the lungs is calculated from the dilution of the inspired $\mathrm{He}$ according to the equation,

Initial CO concentration He concentration in the in the expired alveolar sample

$$
\begin{aligned}
& =\frac{\text { expired alveolar sample }}{\text { Inspired He concentration }} \\
& \times \text { Inspired CO concentration }
\end{aligned}
$$

Knowing the change in $\mathrm{CO}$ concentration in the alveolar sample during the period of breath holding, $D_{L}$ can be calculated from Krogh's equation (9).

$$
\begin{aligned}
D_{L} & {\left[\frac{\text { In ml. COSTPD }}{\text { Min. Xmm. Hg CO tension }}\right] } \\
= & \frac{\text { Alveolar volume (STPD) } 60}{\text { Time in seconds X (barometric pressure-47) }} \\
& \times \text { Natural logarithm }\left[\begin{array}{r}
\text { Initial CO concentration in the } \\
\text { Final CO concentration in the } \\
\text { expired alveolar sample }
\end{array}\right]
\end{aligned}
$$

The apparatus used for the test is illustrated in Figure 1. It differs from that reported previously $(1,2)$ mainly in its greater simplicity; in these previous communications the expired alveolar $\mathrm{He}$ and/or $\mathrm{CO}$ concentrations were measured at the mouth by recording analytical instruments. The circuit is closed, permitting inspiration from the bag of the Donald-Christie apparatus and expiration into the space around the bag, a spirometer recording the change in respiratory volumes. Tap (A) is used by the operator for collecting the expired alveolar sample. Since the gas mixture is inspired from the level 


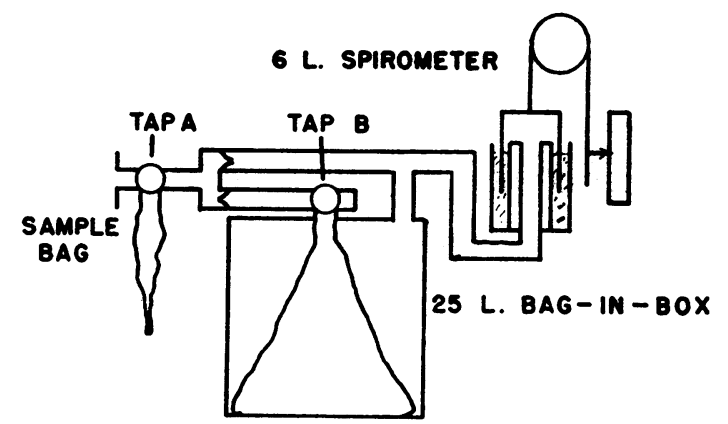

Fig. 1. Diagram of the Apparatus for Measuring Dz in Patients

of the residual volume, the alveolar volume equals the residual volume, ${ }^{7}$ which was measured by a modification of the He closed-circuit technique (10) or by the nitrogen wash out method (11), plus the inspired volume, which was measured directly from the spirometer tracing. The duration of breath holding was timed from the start of inspiration to the start of the collection of the alveolar sample as measured on the spirometer tracing (paper speed $0.44 \mathrm{~cm}$. per second; precision \pm 0.1 seconds). A breath holding period of ten seconds was chosen because this is long enough to produce an accurately measurable fall in alveolar CO concentration and yet is well within the breath holding limits of most patients.

As previously described (1), the alveolar gas samples were analyzed for $\mathrm{CO}$ in an infra-red analyzer, ${ }^{8}$ after passing over calcium chloride. Correction for $\mathrm{CO}_{2}$ interference should be made where necessary but the $\mathrm{CO}_{2}$ sensitivity of the analyzer used in these studies was found to be negligible, 5 per cent $\mathrm{CO}_{2}$ producing a deflection equivalent to less than 0.0005 per cent $\mathrm{CO}$. Readings of percentage $C O$ were precise to within \pm 0.001 per cent.

The alveolar gas samples were analyzed for $\mathrm{He}$ in a catharometer. ${ }^{9}$ Since the catharometer actually measures the total thermal conductivity of the gas mixture, changes in the concentrations of $\mathrm{O}_{2}, \mathrm{~N}_{2}$ (argon included) and $\mathrm{CO}_{2}$ will affect the measurement, in addition to changes in the concentration of $\mathrm{He}$. It was sufficiently accurate to make standard corrections for the presence of $\mathrm{O}_{2}$ and $\mathrm{N}_{2}$, but for $\mathrm{CO}_{2}$ it was necessary to measure the relative thermal conductivity of the gas sample before and after absorption of $\mathrm{CO}_{2}$. The analyses of $\mathrm{He}$ were precise to within \pm 0.05 per cent. About $300 \mathrm{ml}$. of gas were required for the analysis of $\mathrm{CO}$ and $\mathrm{He}$.

$A$ test and a duplicate could be completed within 5 to 10 minutes, but an additional hour was required for the gas analyses and calculations. This does not include the time needed to estimate the residual volume. In an effort to obviate this latter measurement we attempted to

7 More properly, the respiratory dead space should be subtracted from the residual volume. We have neglected this correction, which leads to an overestimate of $D_{L}$ by about 3 per cent in normals.

8 Liston-Becker, Stamford, Conn.

- Cambridge Instrument Company, Cambridge, England. calculate the residual volume from the inspired volume and the dilution of $\mathrm{He}$ in the expired alveolar sample, but found that uneven distribution of inspired gas rendered the resulting value so unreliable as to be useless in all but extreme circumstances.

A motor-driven treadmill set at a gradient of 8 per cent was used for all exercise studies at speeds up to 4.5 miles per hour. For the measurement of minute volume and $\mathrm{O}_{2}$ consumption during exercise breathing air, the expired gas was collected in a 300-liter rubber bag through a low resistance valve. The volume of this gas was measured in a spirometer and the $\mathrm{N}_{2}, \mathrm{O}_{2}$ and $\mathrm{CO}_{2}$ concentrations analyzed in a Scholander apparatus (12). $\mathrm{O}_{2}$ consumption was calculated from these data.

Determinations of lung volumes, including residual volume, maximum breathing capacity, maximal expiratory and inspiratory velocities between 200 and $1200 \mathrm{ml}$. by the method of Danzig and Comroe (13) and uniformity of distribution of inspired gas by the single breath method of Comroe and Fowler (14) were performed on each patient in the pulmonary function laboratory. Subject 22 and Patients 2, 8, 11 and 24 were studied by bronchospirometry and $D_{\mathrm{L}}$ measured in each lung.

\section{SUBJECTS}

Twenty-eight normal subjects (Table I), 16 males and 12 females, ranging in age from 8 to 72 years and in surface area from 0.98 to 2.12 square meters were studied. Most of these subjects were either physicians or laboratory personnel, who had no significant history of pulmonary or cardiac disease, were able to exercise without discomfort, and reported no pulmonary abnormalities by $x$-ray or physical examination. The remaining subjects had no significant pulmonary disease by history, physical, or $\mathrm{x}$-ray examination.

\section{RESULTS AND DISCUSSION}

\section{A. Some Factors Influencing $D_{L}$ and Their Control}

None of the subjects or patients experienced any difficulty in performing the test and all were able to hold their breath for the ten-second period. However, a number of factors either affected, or might be expected to affect, $D_{\mathrm{L}}$ as measured by the present technique. These factors, their importance in obtaining reproducible estimates of $D_{L}$, and the measures that were taken to control them are discussed below.

\section{Measurement and duration of the breath holding period}

It can be seen from Equation 2, that any error in the measurement of the time of breath holding 
TABLE I

$D_{L}$ in healthy subjects—relationship to age, sex and body size

\begin{tabular}{|c|c|c|c|c|c|c|}
\hline Subject & $\begin{array}{l}\text { Age } \\
\text { years }\end{array}$ & $\begin{array}{l}\text { Height } \\
\text { inches }\end{array}$ & $\begin{array}{l}\text { Weight } \\
\text { pounds }\end{array}$ & $\begin{array}{c}\text { Surface } \\
\text { area } \\
M^{2}\end{array}$ & $\begin{array}{l}\text { No. of } \\
\text { observations } \\
\text { of } D_{L}\end{array}$ & $\frac{\text { Mean } D_{L} * \text { in }}{\frac{m l .}{\min . \times m m . H_{g}}}$ \\
\hline \multicolumn{7}{|l|}{$\begin{array}{l}\text { Young Normal } \\
\text { (8-35 years) }\end{array}$} \\
\hline $\begin{array}{r}1 \\
2 \\
3 \\
4 \\
5 \\
6 \\
7 \\
8 \\
9 \\
10 \\
11\end{array}$ & $\begin{array}{r}33 \\
34 \\
32 \\
35 \\
35 \\
32 \\
8 \\
10 \\
20 \\
32 \\
10\end{array}$ & $\begin{array}{l}72.0 \\
66.0 \\
67.5 \\
74.0 \\
67.0 \\
69.5 \\
53.0 \\
55.0 \\
73.0 \\
73.0 \\
51.0\end{array}$ & $\begin{array}{r}164.0 \\
156.0 \\
134.0 \\
165.0 \\
175.0 \\
157.0 \\
61.0 \\
72.0 \\
175.0 \\
170.0 \\
59.0\end{array}$ & $\begin{array}{l}1.96 \\
1.81 \\
1.72 \\
2.01 \\
1.91 \\
1.87 \\
1.02 \\
1.12 \\
2.04 \\
2.00 \\
0.98\end{array}$ & $\begin{array}{r}11 \\
2 \\
21 \\
7 \\
2 \\
5 \\
2 \\
2 \\
9 \\
2 \\
2\end{array}$ & $\begin{array}{l}26.5 \\
24.9 \\
32.8 \\
34.1 \\
29.0 \\
34.0 \\
11.0 \\
16.5 \\
37.5 \\
34.8 \\
17.3\end{array}$ \\
\hline Mean & 25.6 & 65.6 & 135.3 & 1.68 & 6.0 & 27.1 \\
\hline $\begin{array}{r}12 \\
\text { Female } \\
13 \\
14 \\
15 \\
16 \\
17 \\
18 \\
19 \\
20\end{array}$ & $\begin{array}{l}23 \\
27 \\
20 \\
22 \\
21 \\
26 \\
30 \\
26 \\
18\end{array}$ & $\begin{array}{l}62.5 \\
67.5 \\
64.5 \\
65.0 \\
70.0 \\
65.5 \\
70.5 \\
65.0 \\
67.0\end{array}$ & $\begin{array}{l}102.0 \\
215.0 \\
116.0 \\
140.0 \\
124.0 \\
109.0 \\
140.0 \\
122.0 \\
178.0\end{array}$ & $\begin{array}{l}1.45 \\
2.12 \\
1.55 \\
1.70 \\
1.70 \\
1.49 \\
1.80 \\
1.60 \\
1.94\end{array}$ & $\begin{array}{l}8 \\
2 \\
5 \\
2 \\
2 \\
2 \\
2 \\
3 \\
3\end{array}$ & $\begin{array}{l}19.1 \\
34.8 \\
29.1 \\
22.2 \\
18.8 \\
16.4 \\
27.1 \\
23.8 \\
24.9\end{array}$ \\
\hline Mean & 23.7 & 66.4 & 138.4 & 1.71 & 3.2 & 24.0 \\
\hline \multicolumn{7}{|l|}{$\begin{array}{l}\text { Old Normal } \\
\text { (43-72 years) }\end{array}$} \\
\hline $\begin{array}{l}21 \\
22 \\
23 \\
24 \\
25\end{array}$ & $\begin{array}{l}43 \\
70 \\
44 \\
72 \\
44\end{array}$ & $\begin{array}{l}64.0 \\
68.0 \\
65.5 \\
62.0 \\
62.5\end{array}$ & $\begin{array}{l}118.0 \\
141.0 \\
125.0 \\
131.0 \\
151.0\end{array}$ & $\begin{array}{l}1.56 \\
1.76 \\
1.62 \\
1.60 \\
1.71\end{array}$ & $\begin{array}{l}2 \\
4 \\
2 \\
2 \\
2\end{array}$ & $\begin{array}{l}21.8 \\
24.6 \dagger \\
24.2 \\
20.5 \\
29.4\end{array}$ \\
\hline Mean & 54.6 & 64.4 & 133.2 & 1.65 & 2.4 & 24.1 \\
\hline $\begin{array}{ll}\text { Female } & 26 \\
27 \\
28\end{array}$ & $\begin{array}{l}49 \\
62 \\
68\end{array}$ & $\begin{array}{l}60.0 \\
66.0 \\
62.0\end{array}$ & $\begin{array}{l}116.5 \\
123.0 \\
160.0\end{array}$ & $\begin{array}{l}1.49 \\
1.62 \\
1.74\end{array}$ & $\begin{array}{l}2 \\
2 \\
2\end{array}$ & $\begin{array}{l}22.0 \\
18.5 \\
21.7\end{array}$ \\
\hline Mean & 59.7 & 62.7 & 133.2 & 1.62 & 2.0 & 20.7 \\
\hline
\end{tabular}
cent.

* Coefficient of variation of a single observation in the same individual, including day to day variability, is 8.5 per

† Right lung alone: $11.3,10.9 \mathrm{ml}$. per min. per $\mathrm{mm}$. $\mathrm{Hg}$.

Left lung alone: $9.4,9.9 \mathrm{ml}$. per min. per mm. $\mathrm{Hg}$.

will produce a proportional error in $D_{L}$. The duration of breath holding was measured with a precision of about 1 per cent which results in a permissible error in $D_{\mathbf{L}}$.

Theoretically, the duration of breath holding should not influence $D_{L}$, provided the time is measured correctly. However, $\mathrm{D}_{\mathbf{L}}$ measured at different breath holding times, from 5 to 14 seconds in Subject 3, is plotted against duration of breath holding in Figure 2 and definitely decreases as duration of breath holding increases. This is in agreement with earlier experiments on the alveolar CO disappearance curve, and is most probably due to the uneven distribution of capillary diffusing surface throughout the lung $(1,15)$. For this reason a ten-second period of breath holding has been used in these studies. While $D_{L}$ so obtained may not have the proper absolute value, as a first approximation it should be valid for comparative purposes. The breath holding time is not ex- 


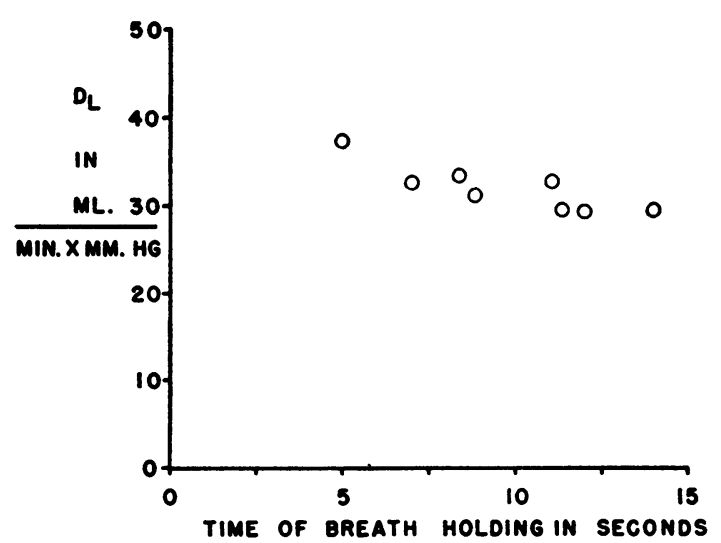

Fig. 2. The Effect upon Calculated De of Varying the Period of Breath Holding

tremely critical; $D_{\mathrm{L}}$ measured at 9 seconds was 1.6 per cent more and at 11 seconds was 1.6 per cent less than its interpolated value at the standard breath holding time of 10 seconds (Figure 2 ).

The untrained subject takes about 1.5 seconds to inspire the gas mixture containing $\mathrm{CO}$, less than a second to expire the volume of gas needed to wash out his respiratory dead space $(750 \mathrm{ml}$. or more), and between one and two seconds to deliver an adequate $(300 \mathrm{ml}$.) alveolar sample. The period of breath holding was measured from the beginning of inspiration to the beginning of expiration of the alveolar sample (after the dead space wash out) because this approximates the average period the gas molecules were in the lung. If inspiration is prolonged, this estimate of the average time the $\mathrm{CO}$ molecules were in the lung will be too great, since much of the $\mathrm{CO}$ will not have been in the lung for this period and $D_{\mathbf{L}}$ will be underestimated. When inspiration was slowed to the extent that it occupied over half of the 10-second period of breath holding, $D_{\mathbf{L}}$ decreased a maximum of 13 per cent in Subject 3, falling from a control value of 30.3 to 27.6 and $26.3 \mathrm{ml}$. per min. per $\mathrm{mm}$. $\mathrm{Hg}$. In addition, inspiration is almost never slowed to this degree in disease states, so that errors from this cause are probably small. If expiration is prolonged, a more common clinical finding, the major effect is to increase the period of collection of the alveolar sample. Since this period is not included in the measured time of breath holding, the latter will in effect be underestimated and $D_{L}$ will be overestimated. Also, slowing either inspiration and/or expiration will decrease the true average alveolar volume during breath holding to something less than that assumed, i.e., residual volume plus total inspired volume, which will produce an overestimate of true $D_{L}$. The actual distortion of $D_{L}$ depends on the summation of these various effects, and was investigated empirically in two subjects who voluntarily altered their rate of delivery of the expired sample. The time needed to wash out the respiratory dead space was maintained at about 1.0 second representing a flow rate of approximately $750 \mathrm{ml}$. per sec. or $45 \mathrm{~L}$. per min., which most patients can develop for at least the first part of expiration.

$\mathrm{D}_{\mathrm{L}}$ was $30.9,32.0$ and $36.1 \mathrm{ml}$. per min. per $\mathrm{mm}$. $\mathrm{Hg}$ with collection periods of $2.1,4.5$, and 8.1 seconds, respectively, in Subject 3, and 33.3, 37.0, 40.8 , and $42.4 \mathrm{ml}$. per min. per $\mathrm{mm}$. $\mathrm{Hg}$ when the collection periods were $1.0,3.1,3.6$, and $6.5 \mathrm{sec}-$ onds, respectively, in Subject 6 . We concluded that while the duration of the period of collection is not extremely critical, it should be kept less than 2 to 3 seconds, making the total time of expiration, including the time for dead space wash out, less than 3 to 4 seconds. The time for dead space wash out plus sample delivery was measured in nine patients, many of whom had obstructive disease (Patients 1, 2, 11, 12, 17, 19, 22, 25 and 28), without attempting to shorten the time of expiration. In all but one of these patients, an adequate sample was collected in a total expiratory time of less than 3.8 seconds, the remaining patient requiring 4.9 seconds. As a practical matter, the duration of the period of collection of the sample is within the control of the operator, since he starts and stops the collection by turning Tap A (Figure 1). Only a small additional amount of gas is expired after the dead space has been washed out ( 1 second) and 2 additional seconds of expiration have transpired.

\section{The portion of the expired alveolar gas sampled}

The first $750 \mathrm{ml}$. of each expiration were discarded, as this volume is needed to wash out the dead space gas (16). This makes it difficult to use the present technique in patients with a vital capacity much less than a liter; approximately 750 $\mathrm{ml}$. being used to clear the dead space and approximately $300 \mathrm{ml}$. being needed for the analyses.

The present technique consists of calculating, 
from the dilution of the inspired $\mathrm{He}$ concentration, the $\mathrm{CO}$ concentration that existed in the expired sample while it was in the lungs and before any $\mathrm{CO}$ had been absorbed by the blood. While this is valid in the presence of uneven distribution of inspired gas, the question arises whether the particular alveolar sample collected is representative of the whole lung in regard to diffusing capacity. Evidence has been published (1) that the ratio, pulmonary diffusing capacity/alveolar volume, is not the same throughout the lung. It is also known that the early portions of an expiration are derived from better ventilated alveoli than the later portions (16), so it might be expected that the different parts of the expired breath would come from regions of varying diffusing capacity.

To answer this question, $D_{L}$ was estimated from samples collected after 1 liter had been expired (early sample) and after 2.5 liters had been expired (late sample) in six normal subjects and in Patients 4 and 6 , who had chronic obstructive emphysema. The data are given in Table II. In all but two individuals $D_{L}$ was higher in the later sample, the average increase being about 10 per cent, a significant change (probability less than 0.05 but greater than 0.01 ). Some allowance should be made for the fact that expiration took longer and, as discussed above, estimated $D_{L}$ would increase from this cause alone in those experiments in which late samples were collected. While the data suggest that the later parts of an expiration come from alveoli with slightly greater ratios of $D_{L}$ to alveolar volume $\left(V_{\mathbf{A}}\right)$, the change is not very large and should be investigated further with more precise experiments. We conclude that for clinical use it will probably not make any significant difference as to which part of the expired alveolar gas is used to measure $\mathrm{D}_{\mathrm{L}}$, because the data here, obtained under grossly exaggerated circumstances, show an average change in $D_{L}$ of only 10 per cent. In many patients there is only sufficient expired volume for one $300-\mathrm{ml}$. alveolar sample in any case. If a large expired volume is available, the alveolar sample is collected from the second liter.

An interesting question is why, if different parts of the breath contain differing contributions from the 'poorly ventilated' and 'well ventilated' alveoli, and if there is indeed non-uniform distribution of $D_{L}$ among the different alveoli, is there not more of a difference between the values of $D_{\mathbf{L}}$ obtained from the early and late parts of the breath? The present experiments were performed mainly to ascertain whether this factor is of great importance in making measurements in patients using the present technique and apparatus and not to give a quantitative answer to this problem. However, it should be pointed out that even if inspired gas is distributed unevenly to the different alveoli, if it is distributed without regard to the diffusing capacity of each alveolus, any sample of expired alveolar gas will give the same value of $D_{L}$ as any other, albeit not the correct total $D_{L}$.

\section{Intrathoracic pressure}

During the period of breath holding the glottis is normally closed and either the chest is relaxed, being supported by the contained gas, or actually develops expiratory force. In both cases intrathoracic pressure rises, which might impede venous return and decrease cardiac output tending to decrease $D_{\mathbf{L}}(2-4,17,18)$. In order to determine the sensitivity of $D_{L}$ to changes in intrathoracic pressure, simultaneous measurements of $D_{L}$ and intraesophageal pressure were made in three normal subjects during a Valsalva maneuver. In Subject 3 , when intraesophageal pressure rose $37 \mathrm{~mm}$. $\mathrm{Hg}$, $D_{L}$ did not change from its control value of 29.4 $\mathrm{ml}$. per min. per $\mathrm{mm}$. Hg. In Subject 6 when intraesophageal pressure rose $64 \mathrm{~mm}$. $\mathrm{Hg}, \mathrm{D}_{\mathbf{L}}$ de-

TABLE II

Effect upon $D_{L}$ of sampling different parts of the expired alveolar gas

\begin{tabular}{|c|c|c|c|}
\hline \multirow[b]{2}{*}{ Subject } & \multirow[b]{2}{*}{ Diagnosis } & \multicolumn{2}{|c|}{$\begin{array}{c}\mathrm{DL}_{\mathrm{L}} \\
\frac{m l .}{\min . \times m m . \mathrm{Hg}}\end{array}$} \\
\hline & & $\begin{array}{c}\text { Early } \\
\text { alveolar } \\
\text { sample* }\end{array}$ & $\begin{array}{c}\text { Late } \\
\text { alveolar } \\
\text { sample† }\end{array}$ \\
\hline \multirow[t]{2}{*}{$\begin{array}{l}1 \\
3 \\
4 \\
9 \\
12 \\
22 \\
\text { Pt. } 4 \\
\text { Pt. } 6\end{array}$} & $\begin{array}{l}\text { Normal } \\
\text { Normal } \\
\text { Normal } \\
\text { Normal } \\
\text { Normal } \\
\text { Normal } \\
\text { Emphysema } \\
\text { Emphysema }\end{array}$ & $\begin{array}{l}22.6 \\
36.9 \\
31.0 \\
38.3 \\
18.8 \\
24.6 \\
20.5 \\
32.3\end{array}$ & $\begin{array}{l}25.1 \\
38.6 \\
30.3 \\
44.6 \\
17.8 \\
29.2 \\
22.6 \\
34.2\end{array}$ \\
\hline & Mean & 27.5 & 30.3 \\
\hline
\end{tabular}

* Early sample : mean volume of 1.0 liters expired before sampling.

† Late sample: mean volume of 2.5 liters expired before sampling. 
creased from 37.4 to $33.2 \mathrm{ml}$. per min. per $\mathrm{mm}$. $\mathrm{Hg}$ and in $A B D$, one of our colleagues, when intraesophageal pressure rose $44 \mathrm{~mm}$. $\mathrm{Hg}, \mathrm{D}_{\mathrm{L}}$ decreased from 36.7 to $30.5 \mathrm{ml}$. per min. per $\mathrm{mm}$. $\mathrm{Hg}$. Since, under these extreme conditions, $D_{L}$ decreased a maximum of 17 per cent, it is unlikely that the variations in intrathoracic pressure normally encountered during breath holding would be a major cause of changes in $D_{\mathbf{L}}$.

As stated in the discussion of the variations in $\mathrm{D}_{\mathbf{L}}$ with body position (vide infra), a 100 per cent increase in cardiac output during exercise is associated with about a 30 per cent increase in $D_{\mathbf{L}}$. We assume that the changes in intrathoracic pressure in these experiments were either not great enough or not of sufficient duration to produce changes in cardiac output of this magnitude.

\section{Effects of variation in lung volume}

Krogh (9) reported that $D_{L}$ increased proportionally to alveolar volume above midcapacity which if true would necessitate correcting the measured values of $D_{L}$ to a standard volume in the manner she did. However, other work from this laboratory (19) suggests that $D_{L}$ does not change markedly with lung volume, but rather that Krogh's results were exaggerated by the uneven distribution of inspired gas. In order to clarify this particular point for the exact conditions of the test, $D_{\mathbf{L}}$ was measured at different alveolar volumes in five normal subjects and the data are presented in Table III. When alveolar volume increased an average of 56 per cent, $D_{L}$ increased an average of only 9 per cent, while according to Krogh's data the increase should have been ap- proximately 50 per cent. For this reason we have made no corrections for differences in lung volume.

\section{Position of the body}

The $D_{L}$ of seven healthy subjects was measured in the supine, sitting and (except for one subject) standing positions. The results are presented in Table IV. The appropriate position was adopted for five minutes before each test. $D_{\mathbf{L}}$ was greater in the supine than in the sitting position in all seven subjects (a significant change; probability less than 0.01) and higher in the sitting than in the standing position in five out of six subjects (not a significant change; probability 0.11 ). Since the values for residual volume used in the calculation of $D_{\mathbf{L}}$ were measured in the sitting position, the significance of the changes in $D_{L}$ depends on the constancy of the residual volume with changes in position. Therefore, the original calculations of $D_{\mathrm{L}}$ have been 'corrected' assuming a 20 per cent decrease in residual volume on changing from a sitting to a standing position and a 30 per cent increase on changing from a sitting to a supine position, the largest changes in residual volume reported in the literature $(20,21)$. When the corrections were applied, $D_{L}$ was still found to be greater in the supine than in the sitting position in six out of seven subjects, but there was no longer a significant alteration on changing from sitting to standing. We measured the residual volume of Subject 9 (whose $D_{\mathbf{L}}$ decreased most on standing) by the method of Darling, Cournand, and Richards (11) in the sitting, standing, and supine positions and found no significant change $(1168,1250$, and $1178 \mathrm{ml}$. BTPS, respectively). We concluded

TABLE III

Dependence of $D_{L}$ on alveolar volume

\begin{tabular}{|c|c|c|c|c|c|}
\hline \multirow[b]{2}{*}{ Subject } & \multicolumn{2}{|c|}{ Small alveolar volume* } & \multicolumn{2}{|c|}{ Large alveolar volume* } & \multirow[b]{2}{*}{$\begin{array}{l}\text { Change } \\
\text { in } \underset{\%}{\mathrm{D}} \mathrm{r}\end{array}$} \\
\hline & $\begin{array}{l}\text { Alveolar } \\
\text { volume } \\
\text { ml. } \\
S T P D\end{array}$ & 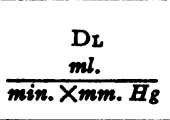 & $\begin{array}{l}\text { Alveolar } \\
\text { volume } \\
\text { STPl. }\end{array}$ & $\frac{\mathrm{D}_{\mathrm{L}}}{\mathrm{ml.}}$ & \\
\hline \multirow[t]{2}{*}{$\begin{array}{r}3 \\
4 \\
9 \\
12 \\
14\end{array}$} & $\begin{array}{l}2,980 \\
3,240 \\
3,260 \\
2,385 \\
2,910\end{array}$ & $\begin{array}{l}28.4 \\
31.2 \\
42.8 \\
16.1 \\
23.8\end{array}$ & $\begin{array}{l}\mathbf{4}, 700 \\
\mathbf{5 , 0 6 0} \\
\mathbf{5 , 1 6 0} \\
\mathbf{3 , 4 9 0} \\
\mathbf{4 , 6 9 0}\end{array}$ & $\begin{array}{l}32.1 \\
33.1 \\
36.1 \\
19.0 \\
29.6\end{array}$ & $\begin{array}{r}+13 \\
+6 \\
-16 \\
+18 \\
+24\end{array}$ \\
\hline & & & & Average change & +9 \\
\hline
\end{tabular}

* Data are single values of $D_{\mathbf{L}}$. 
TABLE IV

The effect of change in position upon $D_{L}$

\begin{tabular}{|c|c|c|c|c|c|}
\hline \multirow[b]{3}{*}{ Subject } & \multirow[b]{3}{*}{ Sitting } & \multicolumn{2}{|r|}{$\begin{array}{c}\mathrm{D}_{\mathrm{L}} \\
\frac{m l .}{\min . \times m m . H_{g}}\end{array}$} & & \\
\hline & & \multicolumn{2}{|c|}{ Supine } & \multicolumn{2}{|c|}{ Standing } \\
\hline & & "Uncorrected" & "Corrected"* & "Uncorrected" & "Corrected"* \\
\hline $\begin{array}{r}1 \\
3 \\
4 \\
9 \\
12 \\
13 \\
14\end{array}$ & $\begin{array}{l}25.4 \\
30.7 \\
31.2 \\
37.7 \\
17.2 \\
36.6 \\
31.3\end{array}$ & $\begin{array}{l}30.5 \\
34.4 \\
37.0 \\
40.6 \\
20.7 \\
43.0 \\
32.4\end{array}$ & $\begin{array}{l}28.8 \\
32.8 \\
34.2 \\
38.1 \\
18.9 \\
40.0 \\
30.2\end{array}$ & $\begin{array}{l}22.5 \\
29.8 \\
25.7 \\
30.6 \\
18.2 \\
29.9\end{array}$ & $\begin{array}{l}23.8 \\
32.2 \\
28.9 \\
33.3 \\
20.1 \\
32.2\end{array}$ \\
\hline Mean & 30.0 & 34.1 & 31.8 & 26.2 & 28.4 \\
\hline
\end{tabular}

* $\mathrm{D}_{\mathrm{L}}$ calculated on the assumption that the change from the sitting to supine position produces a 20 per cent reduction in residual volume and from sitting to standing a 30 per cent increase in residual volume.

that $\mathrm{D}_{\mathrm{L}}$ was probably greater in the lying than in the sitting position, and possibly greater in the sitting than in the standing position, and, for purposes of comparison, have made all measurements of $\mathrm{D}_{\mathrm{L}}$ sitting. The possibility that changes in cardiac output alone caused the observed changes in $D_{\mathbf{L}}$ in the different positions was unlikely for the following reasons. In a recent study by Donald, Bishop, Cumming, and Wade (22) cardiac output was found to increase 6 to 7 per cent on changing from the sitting to the supine position. According to other data of this same group (23) cardiac output breathing air would approximately double when $\mathrm{O}_{2}$ consumption was increased to $2000 \mathrm{ml}$.

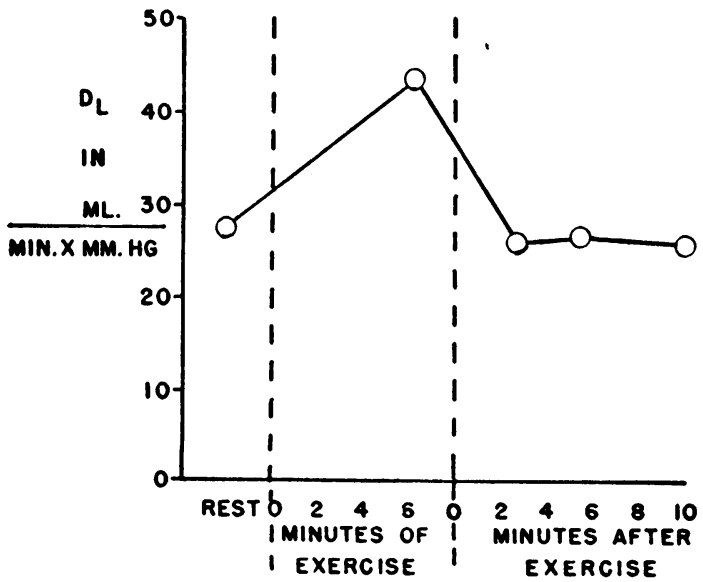

Fig. 3. The Recovery of $D_{\mathrm{L}}$ Following Exercise

The exercise consisted of walking at 41/2 miles per hour on an 8 per cent gradient and corresponded to an $\mathrm{O}_{2}$ consumption of about $2500 \mathrm{ml}$. per min. per min. from rest. According to the data in Figure 4, relating $\mathrm{D}_{\mathrm{L}}$ and $\mathrm{O}_{2}$ consumption during exercise, a 100 per cent increase in cardiac output produces about a 30 per cent increase in $D_{L}$. If this relationship were linear the effect of a 6 per cent increase in cardiac output would be hardly measurable.

\section{Variation in $D_{L}$ with alveolar $\mathrm{O}_{2}$ tension}

$D_{L}$ decreases as alveolar $\mathrm{O}_{2}$ tension is raised (1) presumably because the resultant rise in capillary $\mathrm{O}_{2}$ tension decreases the rate of the combination of $\mathrm{CO}$ with intracorpuscular hemoglobin $(6,7)$ (see Footnote 6$). \quad D_{L}$ measured while breathing

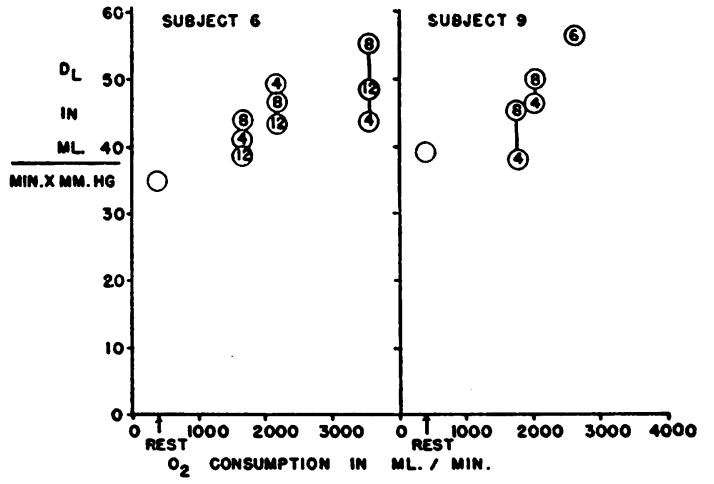

Fig. 4. Dl in Relation to $\mathrm{O}_{2}$ Consumption during EXERCISE

The figures within the circles indicate the duration of exercise in minutes at the time of measurement. The measurements were made at rest, and during exercise at 3,4 , and approximately 5 miles per hour on an 8 per cent gradient. 
approximately 100 per cent $\mathrm{O}_{2}$ may be as low as half its value breathing air (24). Similarly, if the mean capillary $\mathrm{O}_{2}$ tension during the test is below its usual value of $120 \mathrm{~mm} . \mathrm{Hg}, \mathrm{D}_{\mathrm{L}}$ will be overestimated. Over a range of mean capillary $\mathrm{O}_{2}$ tension from 40 to $200 \mathrm{~mm}$. $\mathrm{Hg}$ the correct $\mathrm{D}_{\mathrm{L}}$ equals measured $D_{\mathbf{L}} \times(0.70+0.0027$ mean capillary $\mathrm{O}_{2}$ tension in $\mathrm{mm}$. $\mathrm{Hg}$ ) (24). While a high mean capillary $\mathrm{O}_{2}$ tension can be avoided by keeping the inspired $\mathrm{O}_{2}$ concentration at about 21 per cent, a low mean capillary $\mathrm{O}_{2}$ tension can occur in disease where there is interference with the oxygenation of the capillary blood. It is of course the mean capillary and not the arterial $\mathrm{O}_{2}$ tension which is of importance in affecting the rate of $\mathrm{CO}$ uptake by the red cells. In the data presented in this paper, no correction has been made for changes in capillary $\mathrm{O}_{2}$ tension for two reasons. (a) From a practical standpoint, patients with pulmonary disease will tend to have mean capillary $\mathrm{O}_{2}$ tensions less than $120 \mathrm{~mm}$. $\mathrm{Hg}$ during the period of breath holding, which will artificially increase $D_{L}$. Therefore a patient with a reduced $D_{L}$ most probably has impaired diffusion, although it may be more serious than consideration of the measured value of $D_{L}$ would indicate. (b) It is unlikely that the mean capillary $\mathrm{O}_{2}$ tension in the alveoli which contribute the expired alveolar sample will ever drop below $40 \mathrm{~mm}$. $\mathrm{Hg}$, in which case according to the relationship given above, $D_{\mathbf{L}}$ would be overestimated by 19 per cent. However, in this situation the proper $D_{\mathbf{L}}$ would be so reduced below its normal value that an error of this magnitude would not be of major importance. Therefore, for clinical purposes the effect of a decreased mean capillary $\mathrm{O}_{2}$ tension can be neglected.

\section{Importance of venous $\mathrm{COHb}$}

If an individual has a significant amount of $\mathrm{COHb}$ in his blood, this will impede further diffusion of $\mathrm{CO}$ across the pulmonary membrane, because a certain plasma $\mathrm{CO}$ tension will exist in equilibrium with the $\mathrm{COHb}$. This blood $\mathrm{CO}$ tension can be calculated from the Haldane relation,

$210 \mathrm{CO}$ tension (or gas concentration)

$\mathrm{O}_{2}$ tension (or gas concentration)

$$
=\frac{\mathrm{COHb} \text { concentration }}{\mathrm{O}_{2} \mathrm{Hb} \text { concentration }}
$$

with the proviso that no large amounts of reduced $\mathrm{Hb}$ are present (15). In an extreme case, such as that of a heavy smoker who has as much as 10 per cent $\mathrm{COHb}$ in his blood (25), the equilibrated plasma $\mathrm{CO}$ tension would be less than

$$
\begin{aligned}
& \frac{10 \text { per cent } \mathrm{COHb}}{90 \text { per cent } \mathrm{O}_{2} \mathrm{Hb}} \times \frac{17.5 \text { per cent } \mathrm{O}_{2}}{210} \\
& \text { or } 0.0092 \text { per cent } \mathrm{CO},
\end{aligned}
$$

assuming the capillary $\mathrm{O}_{2}$ tension equal to alveolar $\mathrm{O}_{2}$ tension $\left(125 \mathrm{~mm}\right.$. $\mathrm{Hg}$ or 17.5 per cent $\mathrm{O}_{2}$ ) and capillary $\mathrm{O}_{2} \mathrm{Hb}$ equal to arterial $\mathrm{O}_{2} \mathrm{Hb}$. This equilibrated blood $\mathrm{CO}$ concentration $(0.0092$ per cent) should be subtracted from both the initial and final $\mathrm{CO}$ concentrations in the expired alveolar sample (15). If the subject had an alveolar volume of 6 liters, an initial CO concentration of 0.15 per cent, and a true $D_{L}$ of $30 \mathrm{ml}$. per min. per mm. $\mathrm{Hg}$, his alveolar $\mathrm{CO}$ concentration would be 0.087 per cent $\mathrm{CO}$ at the end of 10 seconds. If one ignored the presence of the COHb in the blood, $\mathrm{D}_{\mathrm{L}}$ would apparently be $27.4 \mathrm{ml}$. per min. per $\mathrm{mm}$. $\mathrm{Hg}$, an error of 8 per cent. Since this is an extreme case and since it would add greatly to the complexity of the test to measure blood $\mathrm{COHb}$, we have not estimated blood $\mathrm{COHb}$ in each individual. However, all individuals were questioned about their smoking habits, and an effort was made to keep the initial $\mathrm{CO}$ concentration high enough to minimize this error.

\section{Time interval at which $D_{L}$ can be repeated}

The estimate of $D_{L}$ can be repeated after an interval that depends upon the rate of elimination of the previously inspired $\mathrm{He}$ and $\mathrm{CO}$ from the alveolar gas. Although one might expect it would take more than 10 minutes to wash all the $\mathrm{He}$ from the alveoli of an emphysematous patient, when the expired alveolar gas in three healthy subjects and one patient with severe emphysema was examined approximately 2 minutes after performing a breath holding test, no He could be detected by the catharometer (less than 0.05 per cent). Following breath holding each individual automatically took a number of deep breaths, which apparently were sufficient to wash out the $\mathrm{He}$. During exercise studies, it would be expected that the He would be washed out even faster. CO will disappear from the alveoli at a considerably faster rate than 
the $\mathrm{He}$ since it is absorbed by the blood in addition to being washed out by inspired gas. Therefore, we considered it permissible to repeat measurements of $D_{L}$ after 2 minutes.

There will be an increase in blood $\mathrm{COHb}$ with each estimation of $D_{L}$ but calculation shows this to be small. For instance, if an individual starts the breath holding period with an alveolar volume of 6 liters and an alveolar $\mathrm{CO}$ concentration of 0.15 per cent, making a total of $9 \mathrm{ml}$. of $\mathrm{CO}$, and absorbed all of this into a total blood CO capacity of $1200 \mathrm{ml}$. , his blood $\mathrm{COHb}$ concentration would rise 0.75 per cent. According to the Haldane relation, under the above conditions the resulting increase in equilibrated gas $\mathrm{CO}$ concentration would be less than

$$
\begin{aligned}
\frac{0.75 \text { per cent } \mathrm{COHb}}{98 \text { per cent } \mathrm{O}_{2} \mathrm{Hb}} \times \frac{17.5 \text { per cent } \mathrm{O}_{2}}{210} \\
=0.0006 \text { per cent } \mathrm{CO}
\end{aligned}
$$

which can be neglected. Therefore, several measurements of $D_{L}$ can be made in succession without increasing the blood $\mathrm{COHb}$ by a significant amount. This has been verified experimentally (1).

Present evidence suggests that no significant alterations in the pulmonary capillaries are produced by the respiratory maneuvers inherent in the present technique (1). Since $D_{L}$ returns to normal several minutes after heavy exercise (vide infra), any changes in the pulmonary capillaries resulting from the effort of one estimation would certainly have subsided within several minutes.

\section{Effect of exercise on $D_{L}$}

The increase in $D_{L^{10}}$ during five minutes of exercise on an 8 per cent gradient at $4 \frac{1}{2}$ m.p.h. in five normal subjects is shown in Table $\mathrm{V}$, and ranged from 42 to 58 per cent (mean of 45.8 per cent). Also shown in Table V are measurements made during the period of recovery from exercise in three subjects, which indicate that $D_{L}$ returns to resting control values within two to three minutes of the cessation of exercise. In the instance of Subject 6 several subsequent minutes of exercise occurred after the value of $43.9 \mathrm{ml}$. per min. per $\mathrm{mm}$. $\mathrm{Hg}$ was obtained, which probably explains the higher value of $47.1 \mathrm{ml}$. per min. per $\mathrm{mm} . \mathrm{Hg}$ during the recovery period. The rapidity of the changes in $D_{L}$ are illustrated in Figure 3, a graph of the findings in Subject 1 before, during and after exercise.

An increase in $D_{L}$ with exercise was first reported by Krogh (9) who found an average 36 per cent rise above the resting level by the breath holding technique, not significantly different from

10 Residual volume determined at rest was used to calculate $\mathrm{D}_{\mathrm{L}}$.

TABLE $\mathbf{V}$

\begin{tabular}{|c|c|c|c|c|c|c|c|c|}
\hline \multirow[b]{2}{*}{ Subject } & \multirow{2}{*}{$\begin{array}{c}\text { DI* } \\
\text { Sitting } \\
\text { before } \\
\text { exercise }\end{array}$} & \multirow{2}{*}{ 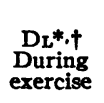 } & \multirow{2}{*}{$\begin{array}{c}\text { Mean \% } \\
\text { increase in } \\
\text { DL during } \\
\text { exercise }\end{array}$} & \multicolumn{5}{|c|}{$\mathrm{DL}_{\mathrm{L}}$ S Sitting after cessation of exercise } \\
\hline & & & & 1 minute & 1 minute & $\begin{array}{c}2-3 \\
\text { minutes }\end{array}$ & $\begin{array}{c}5-6 \\
\text { minutes }\end{array}$ & $\begin{array}{c}9-10 \\
\text { minutes }\end{array}$ \\
\hline 1 & 26.8 & $\begin{array}{l}42.4 \\
42.2\end{array}$ & 58 & & & 25.4 & 26.0 & 24.8 \\
\hline 3 & 36.8 & $\begin{array}{l}52.4 \\
52.5\end{array}$ & 42 & & & & & \\
\hline 4 & 31.2 & $\begin{array}{l}41.4 \\
47.8\end{array}$ & 43 & & & & & \\
\hline 6 & 30.9 & 43.9 & 42 & 47.1 & & 33.5 & 33.6 & \\
\hline 9 & 38.2 & $\begin{array}{l}60.6 \\
49.3\end{array}$ & 44 & & & & & \\
\hline 12 & 18.6 & & & & 24.6 & 20.4 & 20.9 & 19.7 \\
\hline
\end{tabular}

Changes in $D_{L}$ during and after exercise

* $\mathrm{D}_{\mathrm{L}}$ is in $\frac{\mathrm{ml} \text {. }}{\mathrm{min} . \times \mathrm{mm} . \mathrm{Hg}}$.

$\dagger$ Measurements were made between the fourth and sixth minutes of walking on a treadmill at $4 \frac{1}{2}$ m.p.h. on an 8 per cent gradient. 
our average increase of 46 per cent with a modification of her method. On the other hand $\mathrm{DL}_{\mathrm{L}_{2}}$ has been reported as increasing 300 per cent with exercise (3), $D_{\mathbf{L}}$ by the method of Filley, MacIntosh, and Wright as increasing 114 per cent (4) and by the method of Bates, Boucot, and Dormer, 75 to 80 per cent (17). The grade and duration of exercise were not always comparable but since the presently reported $\mathrm{O}_{2}$ uptakes during exercise are as large or larger than those reported during steady state measurements of $\mathrm{D}_{\mathrm{L}}$ and $\mathrm{D}_{\mathrm{LO}_{2}}(4,26$, $27,28)$, it seems apparent that estimates of resting $D_{\mathbf{L}}$ by steady state methods are less than those by breath holding techniques (see section $\mathrm{C}$ ) and increase proportionally more with exercise. There are many theoretical and practical differences between the steady state and breath holding methods which might explain the different absolute values of $\mathrm{D}_{\mathrm{L}}$ (and $\mathrm{D}_{\mathrm{L}_{2}}$ ), but as a first approximation, each method should be consistent within itself implying that the proportional increase in $D_{L}$ from rest to exercise should be the same for all. There is no adequate explanation for the discrepancy at this time. However there is no reason to suspect that the theoretical relation of $\mathrm{D}_{\mathrm{L}}$ to $\mathrm{DL}_{\mathrm{O}_{2}}$, namely, $\mathrm{DL}_{\mathrm{O}_{2}}=1.23 \mathrm{D}_{\mathrm{L}}(9)$, is grossly in error. Although the "breath holding $\mathrm{D}_{\mathrm{L}}$ " is measured at a larger lung volume than the "steady state $D_{\mathbf{L}}$," this should not produce a large change (19). All present methods underestimate the true diffusing capacity of the pulmonary membrane because they ignore the finite velocity of the uptake of $\mathrm{CO}$ or $\mathrm{O}_{2}$ by the corpuscles (5).

The effect upon $D_{L}$ of varying the grade and duration of exercise in Subjects 6 and 9 is recorded in Figure 4. Both subjects were exercised at 3,4 , and 5 m.p.h. at a slope of 8 per cent and $D_{L}$ was measured after 4,8 , and in the case of Subject 6,12 minutes on the treadmill. $\mathrm{O}_{2}$ consumption was measured over half-minute periods between the $D_{L}$ estimations, and was reasonably stable at a given grade of work ( \pm 10 per cent). The values of $D_{L}$ in Figure 4 have been plotted against the average $\mathrm{O}_{2}$ consumption at each grade of exertion. It can be seen that with each increase in $\mathrm{O}_{2}$ consumption, there was some further increase in $D_{L}$ in both subjects. Riley, Shepard, Cohn, Carroll, and Armstrong (28) have reported that $\mathrm{DL}_{\mathrm{O}_{2}}$ reaches a maximum plateau with increasing exercise if it is plotted against $\mathrm{O}_{2}$ con- sumption, and have used the maximal $\mathrm{DL}_{\mathrm{L}_{2}}$ as an index of the total pulmonary capillary surface. The interest in this maximal measurement is based primarily on the expectation that abnormalities which are undetectable in the resting state will become more apparent under the stress of exercise, and secondarily on the fact that the measurement of $\mathrm{D}_{\mathrm{L}_{2}}$ is more precise under these conditions. The question of whether a true maximal diffusing capacity is reached in all subjects is pertinent. $\mathrm{DL}_{2}$ tends to increase with decreasing arterial $\mathrm{O}_{2}$ tension, other things remaining constant (28). Therefore, in measurements of maximal $\mathrm{DL}_{2}$ in which both exercise and anoxia are present there is the distinct possibility that these two factors act to produce an apparent plateau of $\mathrm{DL}_{\mathrm{L}_{2}}$ when it is plotted against $\mathrm{O}_{2}$ consumption. While this criticism does not apply to the steady state measurements of $D_{L}$, only two unequivocal 'plateaux' with increasing exertion were reported (4). Bates, Boucot, and Dormer (17), measuring $D_{\mathbf{L}}$ by a steady state and tidal sampling method, found that of those subjects in whom the presence or absence of a plateau could be fairly assessed, about half showed an increase as the estimated $\mathrm{O}_{2}$ consumption rose from 1.2 to 2.2 liters per min. and half did not. In two subjects who were studied in more detail and whose $\mathrm{O}_{2}$ consumptions were measured, $D_{L}$ could not be said to have reached a plateau. The two subjects studied in detail by the breath holding method in the present report did not reach a plateau (see Figure 4). Ideally, this problem should be investigated by measuring $\mathrm{D}_{\mathrm{L}}$ or $\mathrm{DL}_{\mathrm{L}_{2}}$ during different grades of exercise and as a function of pulmonary blood flow.

In addition to the above studies on $D_{L}$ which suggest that small amounts of exertion are without effect, $D_{L}$ was measured in two of the healthy subjects immediately after they had been walking around the room and was found to be the same as it was after they had been quietly seated for 30 minutes. Therefore, several minutes rest in a chair prior to the measurement of $D_{\mathbf{L}}$ seemed sufficient to provide a standardized condition of activity.

\section{Effect of hyperventilation}

Patients sometimes become apprehensive in the presence of unfamiliar personnel and equipment, 
and hyperventilate. As this might be expected to alter $D_{\mathbf{L}}$, it was measured immediately before and after a period of voluntary hyperventilation, in three normal subjects $(1,6$, and 19). The average control value was 30.9 , the average value after hyperventilation was $30.0 \mathrm{ml}$. per min. per $\mathrm{mm}$. $\mathrm{Hg}$. Although Subject 6 hyperventilated for five minutes, reducing his expired alveolar $\mathrm{CO}_{2}$ concentration from 4.9 to 2.6 per cent, his $\mathrm{D}_{\mathrm{L}}$ only went from 34.8 to $33.7 \mathrm{ml}$. per min. per $\mathrm{mm}$. $\mathrm{Hg}$. Therefore it appears that hyperventilation is not an important factor to control in standardizing the measurement of $D_{\mathbf{L}}$.

In summary, if the measures which have been discussed are used to standardize the procedure, the theoretical cumulative variation in $D_{\mathbf{L}}$ among individuals caused by these various factors could be as high as roughly 30 per cent. In actuality many of these influences cancel out or are constant in a given individual, so that the actual variation in estimated $D_{\mathbf{L}}$ in a single individual is very much less than 30 per cent. In fact, as reported below, the coefficient of variation in a normal subject is only 8.5 per cent. The absolute error in $D_{L}$ is unknown at present; the greatest usefulness of the measurement lies in comparisons.

\section{B. Reproducibility of $D_{L}$}

In order to determine its reproducibility the values of $D_{L}$ in 24 healthy subjects and 19 patients

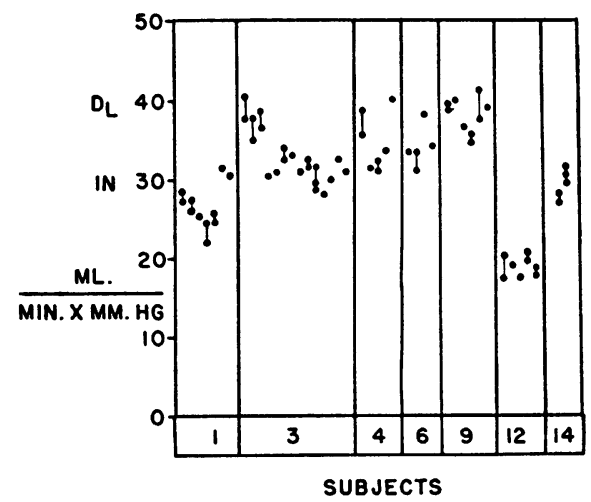

Fig. 5. Repeated Estimations of Resting De in Seven Healthy Subjects

Different days of observation are plotted at different points on the abscissa, progressing from left to right. Observations which are plotted at the same value of the abscissa were obtained on the same day. The longest overall period of observation was seven months, in Subject 4 ; the shortest was two weeks, in Subject 14.

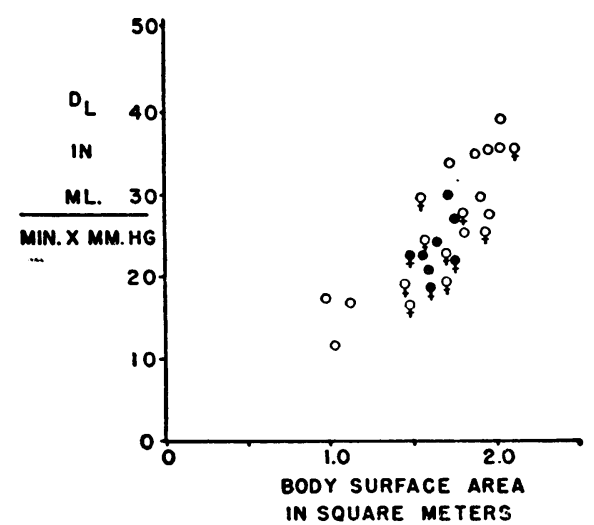

Fig. 6. Resting De in Healthy Subjects Plotted Against Body Surface Area

$O$ male subjects under 35 years of age; $q$ female subjects under 35 years of age; male subjects over 40 years of age; $\$$ female subjects over 40 years of age.

with various lung diseases in whom two or more estimations had been made the same day, were analyzed statistically. The coefficient of variation for a single measurement on the same day in a normal subject was 5.8 per cent, and in a patient, 7.4 per cent. These statistics are not significantly different (probability greater than 0.05). In addition, statistical variations in $D_{\mathbf{L}}$ were analyzed in seven healthy subjects who had been studied on from 2 to 14 different days over periods ranging from 2 to 28 weeks in order to assess the variation in $D_{\mathrm{L}}$ from one day to the next. The data are plotted in Figure 5. The coefficient of variation, including variation both between and within days, was 8.5 per cent. For practical purposes this means that a single estimate of $D_{\mathbf{L}}$ on a given subject has a 76 per cent chance of lying within \pm 10 per cent of the true mean value. An analysis of variance was performed on the data: the variation between days had a coefficient of variation of 9.4 per cent, that within a day, 5.8 per cent. These statistics were significantly different; the variation between days was significantly greater than that within a day (probability less than 0.01 ).

\section{C. $D_{L}$ in Healthy Subjects and Its Relation to Body Size, Sex and Age}

The vital statistics and mean $D_{I}$ for each of the 28 healthy subjects are given in Table $\mathrm{I}$. The mean $\mathrm{D}_{\mathrm{L}}$ was $24.9 \mathrm{ml}$. per min. per mm. $\mathrm{Hg}$ with a range from 11.0 to $37.5 \mathrm{ml}$. per min. per $\mathrm{mm}$. $\mathrm{Hg}$. 
$\mathrm{D}_{\mathrm{L}}$ should in general increase with increasing body size, since oxygen consumption increases with body size. $D_{L}$ does increase with surface area as can be seen in Figure 6 . The regression equation was

$$
\begin{array}{r}
D_{\mathbf{L}}=\text { Surface area (in square meters) } \\
\times 18.85-6.8 .
\end{array}
$$

The standard error of estimate was $3.92 \mathrm{ml}$. per min. per $\mathrm{mm}$. Hg. This relationship was highly significant with a correlation coefficient of 0.81 . The data of Krogh show a similar significant correlation of $D_{L}$, as measured by her technique, with surface area (29). $D_{L}$ as measured by a steady end tidal sampling technique does not show a correlation with body size at rest, but does show a correlation with functional residual capacity during exercise, which may reflect body size (17). The practical importance of the present findings is that any attempt to predict a normal $D_{L}$ for a given patient must take body size into account; $D_{L}$ almost doubles over the range of normal adult surface area (see Figure 6). There is a question as to what is the best index of body size. We have chosen surface area, mainly because of its known relation to $\mathrm{O}_{2}$ consumption. However, $D_{L}$ is also significantly correlated with height and weight. The regression equation for $D_{L}$ as a function of height is $D_{L}=$ height (in inches) $\times 0.874$ -31.6 . The correlation coefficient is 0.74 . The regression equation of $D_{L}$ as a function of weight is $D_{L}=$ weight (in pounds) $\times 0.149+5.2$. The correlation coefficient was 0.78 . There is no significant difference among the correlation coeffcients for $D_{L}$ with surface area, weight or height, so there is no statistical reason for choosing among them at this time. It should be noted that since the regression line of $D_{L}$ as a function of surface area does not pass through the origin, simply dividing $D_{L}$ by surface area does not produce an index independent of surface area. Cohn, Carroll, Armstrong, Shepard, and Riley (27) found a regression coefficient of 1.7 for 'maximal' $\mathrm{D}_{\mathrm{LO}_{2}}$ as a function of height in inches, but since these measurements were taken during exercise, while our measurements were made at rest, the difference is not unexpected. Kruhфffer (30) also reports an increase in $D_{\mathbf{L}}$ with height.

The average resting value of $D_{\mathbf{L}}$ in normal subjects, $24.9 \mathrm{ml}$. per min. per $\mathrm{mm}$. $\mathrm{Hg}$, by the pres- ent breath holding technique is not significantly different from the results of Krogh (9) and Bфje (18) using a similar technique. However, it is larger than the comparable values of 16.9 and 17.6 $\mathrm{ml}$. per min. per $\mathrm{mm}$. $\mathrm{Hg}$ for the steady state methods of Filley, MacIntosh, and Wright (4) and Bates, Boucot, and Dormer (17), respectively, as well as being greater than the lower limit of the normal $\mathrm{DL}_{\mathrm{O}_{2}}$, i.e., $15 \mathrm{ml}$. per min. per $\mathrm{mm}$. $\mathrm{Hg}$ (26). While there are many possible explanations for the discrepancies, some of which have been mentioned in the discussion of the effects of exercise or in earlier publications $(1,15)$, this problem should be investigated further.

Although estimates of $D_{L}$ by the present method tend to be lower in women than in men (Figure 6) there was no significant difference between the sexes in the present limited data.

No correlation was found between the resting $\mathrm{D}_{\mathrm{L}}$ and age. Cohn, Carroll, Armstrong, Shepard, and Riley (27) reported a significant decrease in maximal $\mathrm{DL}_{\mathrm{O}_{2}}$ with increasing age, although there is doubt as to whether a maximum had been reached by some of the older subjects who were unable to exercise strenuously. In their studies direct evidence of maximality (no significant change in $\mathrm{DL}_{2}$ at two different levels of oxygen consumption) is available in only two of the eight subjects over 45 years of age and one of these actually showed the highest value for $\mathrm{DL}_{\mathrm{L}_{2}}$ in the entire group. However, indirect evidence of maximality, derived from the behavior of the mean alveolar-capillary $\mathrm{O}_{2}$ gradient, was present in some of the other subjects. In comparing the present report with that of Cohn and his associates, it must be borne in mind that the 'maximal $\mathrm{D}_{\mathrm{L}_{2}}$ ' may be limited by other portions of the circulatory system than the pulmonary capillaries.

One subject (No. 22) was studied by bronchospirometry, and $D_{\mathfrak{L}}$ measured separately in each lung (see Footnote 2, Table I). At the time of these studies it was not technically feasible to measure residual volume in each lung so that residual volume estimates for the whole lung were distributed in the ratio of $\mathbf{5 5}$ per cent on the right side to 45 per cent on the left side (31). While the agreement between $D_{L}$ for the whole lung $(24.6 \mathrm{ml}$. per min. per $\mathrm{mm} . \mathrm{Hg}$ ) and the sum of $D_{\mathrm{L}}$ for the two lungs $(11.1+9.6=20.7 \mathrm{ml}$. per min. per $\mathrm{mm} . \mathrm{Hg}$ ) is quite good, it is interesting 
that in this healthy subject, as well as in four patients (see Table VI), $D_{L}$ for both lungs together is greater than the sum of the $D_{\mathbf{L}}$ 's for the two lungs separately. The distribution of $D_{L}$ between the two sides in the normal subject is approximately in proportion to their relative alveolar volumes.

\section{Measurements of $D_{L}$ in Patients}

The vital statistics, results of pulmonary function tests and mean $D_{L}$, as well as the predicted normal range of $D_{L}$, for the 28 patients are presented in Table VI. The values for $D_{L}$ in the patients are plotted against body surface area in Figure 7 which also contains the normal regression boundaries for \pm twice the standard error of estimate.

$D_{L}$ is theoretically dependent on 1 ) the surface area of the pulmonary capillaries in contact with alveolar gas, 2) the thickness of the pulmonary membrane, and 3 ) the specific resistance to gas diffusion of the tissue making up the membrane. At present these factors cannot be separated. However, in general we would expect $D_{L}$ to be less than normal in any condition in which the number or size of the pulmonary capillaries is decreased, the thickness of the pulmonary membrane increased, or in which the tissue composing the pulmonary membrane is less permeable to gas diffusion. In chronic obstructive emphysema, there is destruction of alveolar septa and pulmonary capillaries, and $D_{L}$ should be decreased (3234 ). Of the patients with emphysema (1 through 7 ), all but two did have abnormally low values of

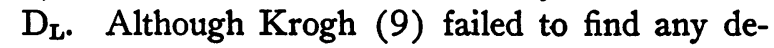
crease in $D_{L}$ in emphysema, this is explicable on the basis of the effects of uneven distribution of inspired gas on her results. Patient 2 had a much larger $D_{L}$ on the right lung than on the left, which was compatible with the interpretation of the $x$-ray films of his chest which showed more gross bullous changes on the left. Patients 8,10,11,12,14 and 15 had various pulmonary diseases which do not attack the capillaries primarily, but in which capillary damage is secondary to destruction or displacement of regions of the lung. The effect on $D_{\mathbf{L}}$ would therefore be expected to depend on the amount of parenchymal tissue lost; in this group, variations in $D_{L}$ were in fact commensurate with

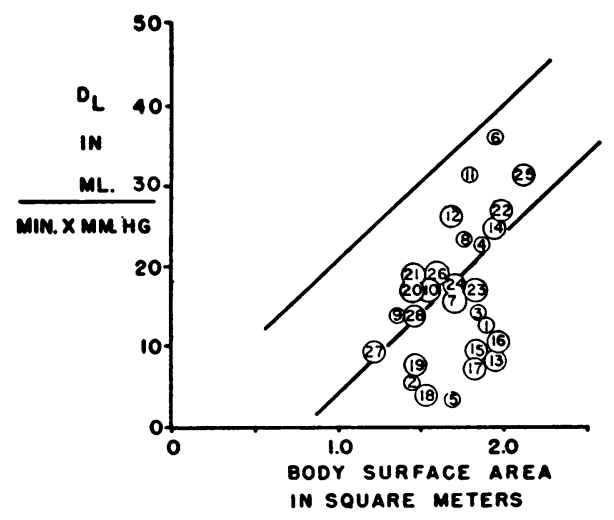

Fig. 7. Resting De in 28 Patients Plotted Against Body Surface Area

The numbers inside the circles indicate the patient recorded in Table VI. The parallel lines are \pm twice the standard error of estimate about the regression line.

the severity and extent of the lesions. Patient 8 had a larger $D_{L}$ in the left lung than in the right, which was compatible with the large amount of tissue displaced by cyst in his right lung. Patient 11 had fibrocavernous tuberculosis in the upper lobe of his right lung which would be expected to decrease the $D_{L}$ in the right lung, as it did. $\mathrm{Pa}$ tient 9 who had bronchial asthma, a disease which does not primarily involve the capillaries (35), had a normal $D_{L}$, while Patients $16,17,18$ and 19 with diseases which are known to attack the pulmonary capillaries, all had very low estimates of $\mathrm{D}_{\mathrm{L}}$ (36). Since Patients 20 and 21 both had pulmonary hypertension with no findings suggesting a congenital cardiac defect, and since in addition both had normal values of $D_{L}$, we concluded that their pulmonary disease had affected the pulmonary arteries and arterioles, but not the pulmonary capillaries. Patient 22 with fibroendocarditis and Patient 23 with mitral stenosis were not in congestive heart failure at the time of the studies, and so it is not unreasonable to find that their pulmonary diffusing capacities are little affected. One would conclude that they had no significant pulmonary capillary damage. Both Patients 13 and 24 had a decreased pulmonary vascular bed, the former because of pneumonectomy, and the latter because of obstruction of the pulmonary artery to the right lung. The $D_{\mathbf{L}}$ on the obstructed side in Patient 24 was slightly more than half that of the contralateral lung. As would be expected, both patients had decreased total $D_{L}$ estimates. Patient 
25 with polycythemia, but with normal pulmonary function tests, had a normal $D_{L}$. While vascular thrombosis is a feature of this disease, it was concluded that the pulmonary capillaries were relatively uninvolved in this patient. Patients 26,27 and 28 all had kyphoscoliosis, which primarily limits the ventilation of the lungs and does not attack the pulmonary capillaries directly; all were within normal limits in their pulmonary diffusing capacity.

We conclude that measurements of $D_{\mathbf{L}}$ by this method are in agreement with the expected de- rangements in pulmonary physiology. From the practical point of view, the great advantages of the method are that it takes so little of the time, requires no arterial samples, and can be repeated often without discomfort to the patient.

\section{SUMMARY}

A modification of the Krogh breath holding technique for the clinical measurement of apparent pulmonary diffusing capacity $\left(D_{\mathbf{L}}\right)$ is described. Reproducibility was investigated in 28 normal subjects ; the coefficient of variation for a single meas-

TABLE VI

$D_{L}$ and pulmonary function tests in patients with various disorders of the chest* $\dagger$

\begin{tabular}{|c|c|c|c|c|c|c|c|c|c|c|}
\hline $\begin{array}{c}\text { Patient } \\
\text { number }\end{array}$ & Diagnosis & Sex & $\begin{array}{l}\text { Age } \\
y r s .\end{array}$ & $\begin{array}{c}\text { Height } \\
\text { inches }\end{array}$ & $\begin{array}{l}\text { Weight } \\
\text { pounds }\end{array}$ & $\begin{array}{c}\text { Surface } \\
\text { area } \\
\mathbf{M}^{2}\end{array}$ & $\begin{array}{l}\mathrm{VC} \\
m l .\end{array}$ & $\begin{array}{l}\text { IC } \\
m l .\end{array}$ & $\begin{array}{c}\text { ERV } \\
m l .\end{array}$ & $\begin{array}{l}\mathrm{RV} \\
m b .\end{array}$ \\
\hline $\begin{array}{l}1 \\
2 \\
3 \\
4 \\
5 \\
6 \\
7\end{array}$ & $\begin{array}{l}\text { Chr. obstr. emphysema } \\
\text { Chr. obstr. emphysema } \\
\text { Chr. obstr. emphysema } \\
\text { Chr. obstr. emphysema } \\
\text { Chr. obstr. emphysema } \\
\text { Chr. obstr. emphysema } \\
\text { Localized obstr. emphy- } \\
\text { sema, right lung }\end{array}$ & $\begin{array}{l}\mathbf{M} \\
\mathbf{M} \\
\mathbf{M} \\
\mathbf{M} \\
\mathbf{M} \\
\mathbf{M} \\
\mathbf{M}\end{array}$ & $\begin{array}{l}55 \\
57 \\
47 \\
75 \\
57 \\
55 \\
28\end{array}$ & $\begin{array}{l}71.5 \\
64 \\
67 \\
67 \\
69 \\
70 \\
66\end{array}$ & $\begin{array}{l}158 \\
101 \\
165 \\
165 \\
122 \\
165 \\
135\end{array}$ & $\begin{array}{l}1.91 \\
1.45 \\
1.86 \\
1.86 \\
1.68 \\
1.96 \\
1.69\end{array}$ & $\begin{array}{l}2840(3900) \\
1760(3450) \\
2680(3800) \\
2980(3270) \\
2000(3720) \\
3260(3820) \\
2000(4200)\end{array}$ & $\begin{array}{l}1530(3120) \\
1170(2760) \\
1990(3040) \\
1800(2620) \\
1150(2980) \\
1950(3060) \\
1420(3360)\end{array}$ & $\begin{array}{r}1340(780) \\
580(690) \\
680(760) \\
1210(650) \\
920(740) \\
1420(760) \\
890(840)\end{array}$ & $\begin{array}{l}3740(1730) \\
2740(1520) \\
3260(1160) \\
2950(1450) \\
4320(1640) \\
3880(1680) \\
1700(1050)\end{array}$ \\
\hline $\begin{array}{r}8 \\
9 \\
10\end{array}$ & $\begin{array}{l}\text { Solitary lung cysts } \\
\text { Bronchial asthma } \\
\text { Bronchiectasis and bron- } \\
\text { cho-pleuro-cutaneous } \\
\text { fistula }\end{array}$ & $\begin{array}{l}\mathbf{M} \\
\mathbf{F}\end{array}$ & $\begin{array}{l}27 \\
14 \\
54\end{array}$ & $\begin{array}{l}73 \\
61 \\
66.5\end{array}$ & $\begin{array}{r}142 \\
95 \\
120\end{array}$ & $\begin{array}{l}1.84 \\
1.37 \\
1.58\end{array}$ & $\begin{array}{l}3750(4560) \\
1690(2600) \\
1820(3650)\end{array}$ & $\begin{array}{r}2550(3650) \\
1360(2080) \\
520(2920)\end{array}$ & $\begin{array}{r}1500(910) \\
620(520) \\
910(730)\end{array}$ & $\begin{array}{l}1870(1140) \\
1290(650) \\
2550(1610)\end{array}$ \\
\hline 11 & $\begin{array}{l}\text { Fibro-cavernous tubercu- } \\
\text { losis (right upper lobe) }\end{array}$ & $\mathbf{M}$ & 60 & 72 & 148 & 1.80 & $3140(3820)$ & $1670(3060)$ & $1600(760)$ & $3110(1680)$ \\
\hline $\begin{array}{l}12 \\
13\end{array}$ & $\begin{array}{l}\text { Bronchial carcinoma } \\
\text { Postpneumonectomy for } \\
\text { bronchial carcinoma }\end{array}$ & $\begin{array}{l}\mathbf{M} \\
\mathbf{M}\end{array}$ & $\begin{array}{l}52 \\
55\end{array}$ & $\begin{array}{l}66 \\
72\end{array}$ & $\begin{array}{l}135 \\
134\end{array}$ & $\begin{array}{l}1.70 \\
1.80\end{array}$ & $\begin{array}{l}2480(3650) \\
3080(3930)\end{array}$ & $\begin{array}{l}1730(2920) \\
1800(3140)\end{array}$ & $\begin{array}{r}750(730) \\
1150(790)\end{array}$ & $\begin{array}{l}1520(1610) \\
2690(1450)\end{array}$ \\
\hline 14 & $\begin{array}{l}\text { Chemical burn of respi- } \\
\text { ratory tract }\end{array}$ & $\mathbf{M}$ & 30 & 72 & 162 & 1.95 & $3250(4400)$ & $2550(3520)$ & $1000(880)$ & $2380(1100)$ \\
\hline 15 & $\begin{array}{l}\text { Chemical burn of respi- } \\
\text { ratory tract }\end{array}$ & $\mathbf{M}$ & 44 & 67 & 164 & 1.84 & $1970(3860)$ & $880(3100)$ & $1110(760)$ & $1870(1190)$ \\
\hline $\begin{array}{l}16 \\
17 \\
18 \\
19 \\
20\end{array}$ & $\begin{array}{l}\text { Diffuse interstitial fibrosis } \\
\text { Diffuse interstitial fibrosis } \\
\text { Sarcoidosis } \\
\text { Scleroderma } \\
\text { Pulmonary arteriolar } \\
\text { disease }\end{array}$ & $\begin{array}{l}\mathbf{F} \\
\mathbf{F} \\
\mathbf{M} \\
\mathbf{M} \\
\mathbf{M}\end{array}$ & $\begin{array}{l}35 \\
52 \\
53 \\
45 \\
15\end{array}$ & $\begin{array}{l}61 \\
67.5 \\
62 \\
62 \\
66\end{array}$ & $\begin{array}{l}220 \\
153 \\
119 \\
107 \\
101\end{array}$ & $\begin{array}{l}1.97 \\
1.81 \\
1.53 \\
1.46 \\
1.50\end{array}$ & $\begin{array}{l}2600(2830) \\
1500(2830) \\
2860(3400) \\
1780(3550) \\
2050(3140)\end{array}$ & $\begin{array}{r}1800(2260) \\
780(2260) \\
1780(2720) \\
960(2840) \\
1500(2520)\end{array}$ & $\begin{array}{r}740(570) \\
560(570) \\
1360(680) \\
720(710) \\
660(620)\end{array}$ & $\begin{array}{r}2060(870) \\
740(1270) \\
1570(1500) \\
850(1100) \\
1390(780)\end{array}$ \\
\hline 21 & $\begin{array}{l}\text { Pulmonary arteriolar } \\
\text { disease }\end{array}$ & F & 44 & 62.5 & 106 & 1.46 & $2760(2760)$ & $1740(2200)$ & $1120(560)$ & $1520(840)$ \\
\hline $\begin{array}{l}22 \\
23 \\
24\end{array}$ & $\begin{array}{l}\text { Fibroendocarditis } \\
\text { Mitral stenosis } \\
\text { Obstructed right pul- } \\
\text { monary artery }\end{array}$ & $\begin{array}{l}\mathbf{M} \\
\mathbf{M} \\
\mathbf{M}\end{array}$ & $\begin{array}{l}31 \\
28 \\
50\end{array}$ & $\begin{array}{l}72 \\
70.5 \\
64.5\end{array}$ & $\begin{array}{l}169 \\
137 \\
145\end{array}$ & $\begin{array}{l}1.97 \\
1.80 \\
1.71\end{array}$ & $\begin{array}{l}4150(4400) \\
3300(4380) \\
3880(3620)\end{array}$ & $\begin{array}{l}3100(3520) \\
2260(3500) \\
2670(2900)\end{array}$ & $\begin{array}{r}1050(880) \\
980(880) \\
1780(720)\end{array}$ & $\begin{array}{l}1920(1100) \\
1670(1120) \\
1740(1580)\end{array}$ \\
\hline $\begin{array}{l}25 \\
26 \\
27 \\
28\end{array}$ & $\begin{array}{l}\text { Polycythemia vera } \\
\text { Kyphoscoliosis } \\
\text { Kyphoscoliosis } \\
\text { Kyphoscoliosis }\end{array}$ & $\begin{array}{l}\mathbf{M} \\
\mathbf{F} \\
\mathbf{F}\end{array}$ & $\begin{array}{l}39 \\
17 \\
46 \\
30\end{array}$ & $\begin{array}{l}72 \\
67 \\
50 \\
61\end{array}$ & $\begin{array}{r}200 \\
111 \\
99 \\
102\end{array}$ & $\begin{array}{l}2.13 \\
1.58 \\
1.22 \\
1.41\end{array}$ & $\begin{array}{r}6300(4250) \\
1920(2940) \\
950(2180) \\
1050(3750)\end{array}$ & $\begin{array}{r}4500(3400) \\
1600(2350) \\
650(1750) \\
820(3000)\end{array}$ & $\begin{array}{r}1640(850) \\
260(590) \\
260(430) \\
420(750)\end{array}$ & $\begin{array}{rr}3280 & (1300) \\
1080 & (760) \\
750 & (670) \\
900 & (950)\end{array}$ \\
\hline
\end{tabular}

* Symbols: VC equals vital capacity; IC equals inspiratory capacity; ERV equals expiratory reserve volume; RV equals residual volume; TLC equals total lung capacity; MBC equals maximal breathing capacity; all lung volumes BTPS.

Whin $†$ Figures in parentheses are predicted normal values.

W.W $F$ RVITLC in young normals should be less than 30 per cent.

Maximum inspiratory (or expiratory) velocities are measured between 200 and $1200 \mathrm{ml}$. of the inspiration (or expiration). Normal values lie between 400 and 600 liters per min. 
TABLE vi-Continued

\begin{tabular}{|c|c|c|c|c|c|c|c|c|}
\hline $\begin{array}{l}\text { Patient } \\
\text { number }\end{array}$ & $\underset{m l .}{\mathrm{TLC}}$ & $\underset{\times 100}{\mathrm{RV} / \mathrm{TLC}}$ & $\begin{array}{c}\mathrm{MBC} \\
L . / \min . / M^{2}\end{array}$ & $\begin{array}{c}\text { Max. exp. } \\
\text { vel. } \S \\
L . / \text { min. }\end{array}$ & $\begin{array}{l}\text { Max. insp. } \\
\text { vel.8 } \\
L . / m i n .\end{array}$ & $\begin{array}{c}\mathrm{N}_{2} \text { single } \\
\text { breath } \\
\text { test\| } \\
\% \mathrm{~N}_{2}\end{array}$ & $\frac{\begin{array}{c}\mathrm{DL}_{\mathrm{L}} \\
\mathrm{ml} .\end{array}}{\min . \times m m . \mathrm{Hg}_{\mathrm{g}}}$ & 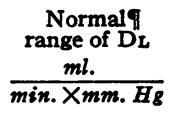 \\
\hline $\begin{array}{l}1 \\
2 \\
3 \\
4 \\
5 \\
6 \\
7\end{array}$ & $\begin{array}{l}6580(5630) \\
4500(4970) \\
5940(4960) \\
5930(4720) \\
6320(5360) \\
7140(5500) \\
3700(5250)\end{array}$ & $\begin{array}{l}57 \\
60 \\
55 \\
50 \\
68 \\
54 \\
46\end{array}$ & $\begin{array}{l}28(44) \\
30(47) \\
18(57) \\
27(58) \\
44(72)\end{array}$ & $\begin{array}{r}37 \\
28 \\
50 \\
50 \\
15 \\
105 \\
76\end{array}$ & $\begin{array}{l}120 \\
220 \\
280 \\
220 \\
150 \\
170 \\
122\end{array}$ & $\begin{array}{r}12.0 \\
13.5 \\
4.6 \\
4.0 \\
8.0 \\
6.4 \\
1.5\end{array}$ & $\begin{array}{l}12.2 \\
6.5^{* *} \\
13.6 \\
21.6 \\
3.5 \\
35.2 \\
15.8\end{array}$ & $\begin{array}{l}21.0-37.0 \\
12.7-28.7 \\
20.0-36.0 \\
20.2-36.2 \\
17.1-33.1 \\
22.0-38.0 \\
17.2-33.2\end{array}$ \\
\hline $\begin{array}{r}8 \\
9 \\
10\end{array}$ & $\begin{array}{l}3620(5700) \\
3980(3250) \\
4370(5260)\end{array}$ & $\begin{array}{l}33 \\
32 \\
58\end{array}$ & $\begin{array}{l}53(72) \\
39(64) \\
44(58)\end{array}$ & $\begin{array}{r}210 \\
53 \\
70\end{array}$ & $\begin{array}{l}165 \\
100 \\
135\end{array}$ & $\begin{array}{l}3.7 \\
0.8\end{array}$ & $\begin{array}{l}22.4 \dagger \dagger \\
14.1 \\
16.7\end{array}$ & $\begin{array}{l}19.9-35.9 \\
11.1-27.1 \\
15.2-31.2\end{array}$ \\
\hline 11 & $6250(5500)$ & 50 & $35(46)$ & 138 & 210 & 4.0 & $31.1 \ddagger \ddagger$ & $19.2-35.2$ \\
\hline $\begin{array}{l}12 \\
13\end{array}$ & $\begin{array}{l}4000(5260) \\
5770(5380)\end{array}$ & $\begin{array}{l}38 \\
47\end{array}$ & $24(58)$ & $\begin{array}{r}150 \\
65\end{array}$ & $\begin{array}{l}220 \\
220\end{array}$ & $\begin{array}{l}1.8 \\
5.7\end{array}$ & $\begin{array}{r}25.6 \\
8.6\end{array}$ & $\begin{array}{l}17.3-33.3 \\
19.2-35.2\end{array}$ \\
\hline 14 & $5630(5500)$ & 42 & $26(70)$ & 115 & 130 & 2.2 & 24.2 & $22.0-38.0$ \\
\hline 15 & 3840 (5050) & 48 & $36(64)$ & 50 & 45 & 4.0 & 9.7 & 19.9-35.9 \\
\hline $\begin{array}{l}16 \\
17 \\
18 \\
19 \\
20\end{array}$ & $\begin{array}{l}4660(3700) \\
2240(4100) \\
4430(4900) \\
2630(4650) \\
3340(3920)\end{array}$ & $\begin{array}{l}44 \\
33 \\
35 \\
32 \\
42\end{array}$ & $\begin{array}{l}36(55) \\
49(47) \\
80(63) \\
64(79)\end{array}$ & $\begin{array}{r}68 \\
200 \\
200 \\
430 \\
140\end{array}$ & $\begin{array}{l}200 \\
158 \\
170 \\
250 \\
250\end{array}$ & $\begin{array}{l}6.6 \\
9.8 \\
8.2 \\
5.3 \\
1.7\end{array}$ & $\begin{array}{r}10.2 \\
7.1 \\
4.0 \\
7.0 \\
17.1\end{array}$ & $\begin{array}{l}22.2-38.2 \\
19.3-35.3 \\
14.2-30.2 \\
12.8-28.8 \\
13.5-29.5\end{array}$ \\
\hline 21 & $4280(3600)$ & 35 & $65(50)$ & 160 & 140 & 0.6 & 18.7 & $12.8-28.8$ \\
\hline $\begin{array}{l}22 \\
23 \\
24\end{array}$ & $\begin{array}{l}6070(5500) \\
4970(5500) \\
5620(5200)\end{array}$ & $\begin{array}{l}32 \\
33 \\
31\end{array}$ & $\begin{array}{l}45(72) \\
44(60)\end{array}$ & $\begin{array}{l}600 \\
300 \\
325\end{array}$ & $\begin{array}{l}370 \\
270 \\
180\end{array}$ & $\begin{array}{l}0.7 \\
2.5 \\
1.5\end{array}$ & $\begin{array}{l}26.3 \\
17.1 \\
17.688\end{array}$ & $\begin{array}{l}22.1-38.1 \\
19.1-35.1 \\
17.4-33.4\end{array}$ \\
\hline $\begin{array}{l}25 \\
26 \\
27 \\
28\end{array}$ & $\begin{array}{l}9580(5550) \\
3000(3700) \\
1700(2850) \\
1950(4700)\end{array}$ & $\begin{array}{l}34 \\
36 \\
44 \\
41\end{array}$ & $\begin{array}{r}117(66) \\
38(63) \\
27(50) \\
30(71)\end{array}$ & $\begin{array}{r}800 \\
122 \\
44 \\
77\end{array}$ & $\begin{array}{r}550 \\
140 \\
89 \\
75\end{array}$ & $\begin{array}{l}1.7 \\
3.0 \\
2.0\end{array}$ & $\begin{array}{r}30.4 \\
17.5 \\
9.4 \\
13.3\end{array}$ & $\begin{array}{r}24.9-40.9 \\
15.2-31.2 \\
8.1-24.1 \\
11.8-27.8\end{array}$ \\
\hline
\end{tabular}

|| The change in $\mathrm{N}_{2}$ concentration between $750 \mathrm{ml}$. and $1250 \mathrm{ml}$. of the expired air should be less than 2.0 per cent. of \pm twice the standard error of estimate about the regression line.

** Patient 2: DL right lung was $3.4 \mathrm{ml} . / \mathrm{min} . / \mathrm{mm}$. $\mathrm{Hg}$; left lung $2.0 \mathrm{ml} . / \mathrm{min} . / \mathrm{mm} . \mathrm{Hg}$.

tt Patient 8: $\mathrm{D}_{\mathrm{L}}$ right lung was $5.6 \mathrm{ml} . / \mathrm{min} . / \mathrm{mm}$. $\mathrm{Hg}$; left lung $10.8 \mathrm{ml} . / \mathrm{min} . / \mathrm{mm}$. Hg.

$\$$ Patient $11: \mathrm{D}_{\mathrm{L}}$ right lung was $10.5 \mathrm{ml} . / \mathrm{min} . / \mathrm{mm}$. Hg; left lung $17.5 \mathrm{ml} . / \mathrm{min} . / \mathrm{mm}$. Hg.

$\$ \$$ Patient 24: $\mathrm{D}_{\mathrm{L}}$ right lung was $4.4 \mathrm{ml} . / \mathrm{min} . / \mathrm{mm}$. $\mathrm{Hg}$; left lung $8.8 \mathrm{ml} . / \mathrm{min} . / \mathrm{mm}$. $\mathrm{Hg}$.

urement on a single subject was 8.5 per cent. $D_{L}$ increased with increasing body surface area, height and weight. It also increased with exercise, returning to control values within several minutes of the cessation of exercise. $D_{\mathbf{L}}$ rose with increasing degrees of exercise, but did not reach a maximal plateau in the subjects studied. $D_{\mathbf{L}}$ varied slightly with posture, being greatest when the subject was supine, less when sitting and least when standing. The importance of these and other factors in obtaining a standardized estimate of $\mathrm{D}_{\mathbf{L}}$ is discussed.

Measurements of $D_{L}$ were made in 28 patients with various pulmonary diseases. In four patients and one normal subject, $D_{\mathrm{L}}$ was measured sepa- rately in the two lungs. There were no difficulties in performing the test, and the values of $D_{L}$ obtained were consonant with the clinico-pathological diagnosis.

\section{ACKNOWLEDGMENT}

The authors acknowledge the invaluable assistance of Mrs. Rosemary Marshall, Dr. Leon Cander, and Mr. Joel Shapiro in performing these measurements of $D_{\mathbf{L}}$. We also wish to express our appreciation to Dr. J. H. Comroe, Jr. for advice and criticism, to Dr. Arthur DuBois and Dr. Robert Marshall for help in measuring esophageal pressures, to Dr. George Bedell and Dr. Romeiro Neto for performing the pulmonary function tests of the patients studied, and to the entire staff of the pulmonary function laboratory for constant help. 


\section{APPENDIX}

Patients 1 through 6 had histories and physical and $x$-ray findings compatible with a diagnosis of chronic obstructive emphysema, which was confirmed by the pulmonary function tests. Patient 7 was a very much younger man giving a similar history, but $x$-ray studies showed a uniform increase in the translucency of his right lung while his left lung appeared relatively normal. Bronchospirometric studies showed that only 10 per cent of the total lung $\mathrm{O}_{2}$ and $\mathrm{CO}_{2}$ exchange was carried on by the right lung. This patient was considered to have unilateral obstructive emphysema. Patient 8 complained of dyspnea on exertion and chest $x$-ray examination showed one solitary cyst in each lung. Shortly after these studies, the cyst in one lung was removed and the diagnosis was verified. Patient 9 had a history of asthmatic attacks since early childhood, and his physical examination and chest $\mathrm{x}$-rays were compatible with the diagnosis of bronchial asthma. Patient 10 had a history of pneumonia and empyema many years previously and a bronchopleurocutaneous fistula which persisted following open drainage of the chest. This fistula was obvious on physical examination and was occluded during pulmonary function tests. Patient 11 had a history of tuberculosis, and signs of fibro-cavernous tuberculosis in the right upper lobe by physical and $x$-ray examination. This patient had been referred from a sanatorium for lobectomy which was performed after these studies, the diagnosis being confirmed. Patient 12 had complained of cough 9 years previously, at which time his left lung was removed because of a squamous cell epithelioma of the bronchus. He now complained of dyspnea and the remaining lung was overdistended and considered to be emphysematous. Patients 14 and 15 were firemen who had been exposed to corrosive chemical fumes which severely damaged the upper respiratory tract, bronchi and bronchial tree, six weeks prior to these studies. Patient 15 still complained of shortness of breath, and granulation tissue in the trachea mucosa could be demonstrated by bronchoscopic examination at the time of these measurements. Patient 14 had been much less severely affected (as indicated by pulmonary function tests) and was symptom-free when studied. Both patients 16 and 17 had histories, physical examinations and $x$-ray findings compatible with acute diffuse interstitial fibrosis (37). This diagnosis was verified by a lung biopsy in patient 17 . Patient 18 had the typical radiological features of pulmonary sarcoidosis, and biopsy of a cervical lymph node showed sarcoid changes. $\mathrm{Pa}$ tient 19 had generalized cutaneous scleroderma. His chest $x$-ray examination showed the extensive pulmonary fibrosis often seen with this disease, which was verified by pulmonary biopsy. Patient 20 complained of shortness of breath following an attack of varicella 4 months earlier. His heart was enlarged by $x$-ray examination, and pulmonary hypertension was demonstrated by right heart catheterization. Patient 21 also complained of shortness of breath, had a greatly increased pulmonary artery pressure by cardiac catheterization, and enlargement of the pulmonary outflow tract by $x$-ray examination. Since both of these patients had relatively normal ventilatory and distributory function and no evidence of an intracardiac shunt or other congenital heart defect was found by venous catherization in either, they were considered to have primarily pulmonary arterial disease. This was confirmed later at autopsy in patient 20 . Patients 22 and 23 had histories, physical and $x$-ray findings suggestive of chronic rheumatic heart disease with mitral stenosis and well controlled congestive failure at the time of study. Patient 22 had hemosiderosis of the lungs by $x$-ray examination and increased left auricular pressure but no mitral stenosis when the valve was palpated at the time of operation. Biopsy of the auricular appendage was reported as fibroendocarditis. Patient 24 was asymptomatic, having had the absence, or obstruction of his right pulmonary artery discovered on a routine chest film and verified by pulmonary angiography. Since no alternate explanation was forthcoming, it was considered a congenital defect. Patient 25 had recently been diagnosed as polycythemia vera by blood measurements but at the time of the present study had been treated with radioactive phosphorus and had 5.4 million red cells per $\mathrm{mm}^{3}$. He was otherwise in excellent health by history, physical and $\mathrm{x}$-ray examination, and his ventilatory studies were in fact better than predicted for a normal subject. Patients 26,27 , and 28 all had the physical and $x$-ray findings of severe kyphoscoliosis; patient 26 had had his deformity since early childhood and in addition had tuberculosis of the hip at the time of study; patient 27 had been deformed since birth; patient 28 had been deformed since he had had rickets as an infant.

\section{REFERENCES}

1. Forster, R. E., Fowler, W. S., Bates, D. V., and Van Lingen, B., The absorption of carbon monoxide by the lungs during breathholding. J. Clin. Invest., 1954, 33, 1135.

2. Forster, R. E., Cohn, J. E., Briscoe, W. A., Blakemore, W. S., and Riley, R. L., A modification of the Krogh carbon monoxide breathholding technique for estimating the diffusing capacity of the lung; a comparison with three other methods. J. Clin. Invest., 1955, 34, 1417.

3. Lilienthal, J. L., Jr., Riley, R. L., Proemmel, D. D., and Franke, R. E., An experimental analysis in man of the oxygen pressure gradient from alveolar air to arterial blood during rest and exercise at sea level and at altitude. Am. J. Physiol., 1946, 147, 199.

4. Filley, G. F., MacIntosh, D. J., and Wright, G. W., Carbon monoxide uptake and pulmonary diffusing capacity in normal subjects at rest and during exercise. J. Clin. Invest., 1954, 33, 530.

5. Forster, R. E., Roughton, F. J. W., Cander, L., Briscoe, W. A., and Kreuzer, F., The relationship between the diffusing capacity of the pulmonary membrane and pulmonary capillary blood volume in man. Am. J. Physiol., 1955, 183, 615. 
6. Roughton, F. J. W., and Forster, R. E., The relative importance of diffusion and chemical reaction rates in the uptake of $\mathrm{CO}$ and $\mathrm{O}_{2}$ in the lungs. To be published.

7. Roughton, F. J. W., The kinetics of the reaction $\mathrm{CO}+$ $\mathrm{O}_{2} \mathrm{Hb}=\mathrm{O}_{2}+\mathrm{COHb}$ in human blood at body temperature. Am. J. Physiol., 1945, 143, 609.

8. Cander, L., and Forster, R. E., Effects of varying alveolar oxygen tension upon pulmonary membrane diffusing capacity and pulmonary capillary blood volume in man. Am. J. Physiol., 1955, 183, 601.

9. Krogh, M., Diffusion of gases through the lungs of man. J. Physiol., 1915, 49, 271.

10. McMichael, J., A rapid method for determining lung capacity. Clin. Sc., 1939, 4, 167.

11. Darling, R. C., Cournand, A., and Richards, D. W., Jr., Studies on intrapulmonary mixture of gases. III. An open circuit method for measuring residual air. J. Clin. Invest., 1940, 19, 609.

12. Scholander, P. F., Analyzer for accurate estimation of respiratory gases in one-half cubic centimeter samples. J. Biol. Chem., 1947, 167, 235.

13. Danzig, L., and Comroe, J. H., Jr., A critical analysis of rapid spirographic techniques. To be published.

14. Comroe, J. H., Jr., and Fowler, W. S., Lung function studies. VI. Detection of uneven alveolar ventilation during a single breath of oxygen. Am. J. Med., 1951, 10, 408.

15. Forster, R. E., Fowler, W. S., and Bates, D. V., Considerations on the uptake of carbon monoxide by the lungs. J. Clin. Invest., 1954, 33, 1128.

16. Fowler, W. S., Lung function studies. III. Uneven pulmonary ventilation in normal subjects and in patients with pulmonary disease. J. Applied Physiol., 1949, 2, 283.

17. Bates, D. V., Boucot, N. G., and Dormer, A. E., The pulmonary diffusing capacity in normal subjects. J. Physiol., 1955, 129, 237.

18. Bфје, O., Uber die Grösse der Lungendiffusion des Menschen während Ruhe und körperlicher Arbeit. Arbeitsphysiologie, 1933, 7, 157.

19. Forster, R. E., Briscoe, W. A., and Bates, D. V., Pulmonary diffusing capacity at different lung volumes. Federation Proc., 1954, 13, 46.

20. Blair, E., and Hickam, J. B., The effect of change in body position on lung volume and intrapulmonary gas mixing in normak subjects. J. Clin. Invest., 1955, 34, 383.

21. Whitfield, A. G. W., Waterhouse, J. A. H., and Arnott, W. M., The total lung volume and its subdivisions. A study in physiological norms. I. Brit. J. Social Med., 1950, 4, 1.

22. Donald, K. W., Bishop, J. M., Cumming, G., and Wade, O. L., The effect of nursing positions on the cardiac output in man. Clin. Sc., 1953, 12, 199.
23. Donald, K. W., Bishop, J. M., Cumming, G., and Wade, O. L., The effect of exercise on the cardiac output and circulatory dynamics of normal subjects. Clin. Sc., 1955, 14, 37.

24. Forster, R. E., Roughton, F. J. W., Cander, L., Briscoe, W. A., and Kreuzer, F., The apparent pulmonary diffusing capacity for $\mathrm{CO}$ at varying alveolar $\mathrm{O}_{2}$ tensions. To be published.

25. Forbes, W. H., Sargent, F., and Roughton, F. J. W., The rate of carbon monoxide uptake by normal men. Am. J. Physiol., 1945, 143, 594.

26. Donald, K. W., Renzetti, A., Riley, R. L., and Cournand, A., Analysis of factors affecting concentrations of oxygen and carbon dioxide in gas and blood of lungs : results. J. Applied Physiol., 1952, 4, 497.

27. Cohn, J. E., Carroll, D. G., Armstrong, B. W., Shepard, R. H., and Riley, R. L., Maximal diffusing capacity of the lung in normal male subjects of different ages. J. Applied Physiol., 1954, 6, 588.

28. Riley, R. L., Shepard, R. H., Cohn, J. E., Carroll, D. G., and Armstrong, B. W., Maximal diffusing capacity of the lungs. J. Applied Physiol., 1954, 6, 573.

29. Krogh, A., and Krogh, M., On the rate of diffusion of carbonic oxide into the lungs of man. Skandinav. Arch. f. Physiol., 1909, 23, 236.

30. Kruhфffer, P., Studies on the lung diffusion coefficient for carbon monoxide in normal human subjects by means of $\mathrm{C}^{14} \mathrm{O}$. Acta physiol. Scandinav., 1954, 32, 106.

31. Gaensler, E. A., and Cugell, D. W., Bronchospirometry. V. Differential residual volume determination. J. Lab. \& Clin. Med., 1952, 40, 558.

32. Bates, D. V., The uptake of carbon monoxide in health and in emphysema. Clin. Sc., 1952, 11, 21.

33. Shepard, R. H., Cohn, J. E., Cohen, G., Armstrong, B. W., Carroll, D. G., Donoso, H., and Riley, R. L., The maximal diffusing capacity of the lung in chronic obstructive disease of the airways. Am. Rev. Tuberc., 1955, 71, 249.

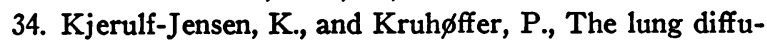
sion coefficient for carbon monoxide in patients with lung disorders, as determined by $\mathrm{C}^{14} \mathrm{O}$. Acta med. Scandinav., 1954, 150, 395.

35. Bates, D. V., Impairment of respiratory function in bronchial asthma. Clin. Sc., 1952, 11, 203.

36. Austrian, R., McClement, J. H., Renzetti, A. D., Jr., Donald, K. W., Riley, R. L., and Cournand, A., Clinical and physiologic features of some types of pulmonary diseases with impairment of alveolarcapillary diffusion. Am. J. Med., 1951, 11, 667.

37. Hamman, L., and Rich, A. R., Acute diffuse interstitial fibrosis of the lungs. Bull. Johns Hopkins Hosp., 1944, 74, 177. 